\title{
Environmental controls on the boron and strontium isotopic composition of aragonite shell material of cultured Arctica islandica
}

\author{
Y.-W. Liu ${ }^{1}$, S. M. Aciego ${ }^{1}$, and A. D. Wanamaker Jr. ${ }^{2}$ \\ ${ }^{1}$ Department of Earth and Environmental Sciences, University of Michigan, 1100 N. University Avenue, \\ Ann Arbor, MI 48109-1005, USA \\ ${ }^{2}$ Department of Geological and Atmosphere Sciences, Iowa State University, Room 12, Science I, \\ Ames, IA 50011-3212, USA
}

Correspondence to: Y.-W. Liu (liuyiwei@umich.edu)

Received: 3 January 2015 - Published in Biogeosciences Discuss.: 10 February 2015

Revised: 23 April 2015 - Accepted: 6 May 2015 - Published: 4 June 2015

\begin{abstract}
Ocean acidification, the decrease in ocean $\mathrm{pH}$ associated with increasing atmospheric $\mathrm{CO}_{2}$, is likely to impact marine organisms, particularly those that produce carbonate skeletons or shells. Therefore, it is important to investigate how environmental factors (seawater $\mathrm{pH}$, temperature and salinity) influence the chemical compositions in biogenic carbonates. In this study we report the first highresolution strontium $\left({ }^{87} \mathrm{Sr} /{ }^{86} \mathrm{Sr}\right.$ and $\left.\delta^{88 / 86} \mathrm{Sr}\right)$ and boron $\left(\delta^{11} \mathrm{~B}\right)$ isotopic values in the aragonite shell of cultured $\mathrm{Arc}$ tica islandica (A. islandica). The ${ }^{87} \mathrm{Sr} /{ }^{86} \mathrm{Sr}$ ratios from both tank water and shell samples show ratios nearly identical to the open ocean, which suggests that the shell material reflects ambient ocean chemistry without terrestrial influence. The ${ }^{84} \mathrm{Sr}-{ }^{87} \mathrm{Sr}$ double-spike-resolved shell $\delta^{88 / 86} \mathrm{Sr}$ and $\mathrm{Sr}$ concentration data show no resolvable change throughout the culture period and reflect no theoretical kinetic mass fractionation throughout the experiment despite a temperature change of more than $15^{\circ} \mathrm{C}$. The $\delta^{11} \mathrm{~B}$ records from the experiment show at least a $5 \%$ increase through the 29-week culture season (January 2010-August 2010), with low values from the beginning to week 19 and higher values thereafter. The larger range in $\delta^{11} \mathrm{~B}$ in this experiment compared to predictions based on other carbonate organisms (2-3\%o) suggests that a species-specific fractionation factor may be required. A significant correlation between the $\Delta \mathrm{pH}\left(\mathrm{pH}_{\text {shell }}-\mathrm{pH}_{\mathrm{sw}}\right)$ and seawater $\mathrm{pH}\left(\mathrm{pH}_{\mathrm{sw}}\right)$ was observed $\left(R^{2}=0.35\right)$, where the $\mathrm{pH}_{\text {shell }}$ is the calcification $\mathrm{pH}$ of the shell calculated from boron isotopic composition. This negative correlation suggests that $A$. islandica partly regulates the $\mathrm{pH}$ of the extrapallial fluid. However, this proposed mech-
\end{abstract}

anism only explains approximately $35 \%$ of the variance in the $\delta^{11} \mathrm{~B}$ data. Instead, a rapid rise in $\delta^{11} \mathrm{~B}$ of the shell material after week 19, during the summer, suggests that the boron uptake changes when a thermal threshold of $>13^{\circ} \mathrm{C}$ is reached.

\section{Introduction}

Since the onset of the Industrial Revolution (ca. AD 1750) the global ocean has absorbed approximately $30 \%$ of the emitted anthropogenic carbon dioxide $\left(\mathrm{CO}_{2}\right)$ causing ocean acidification (IPCC, 2013). The ecological effects from lowering the $\mathrm{pH}$ of the surface ocean on marine organisms, especially those which calcify, will likely be substantial (Doney et al., 2009; Hofmann et al., 2010; Orr et al., 2005), highly variable among taxa (Kroeker et al., 2010; Riebesell et al., 2013), and extend throughout the global ocean (Feely et al., 2004; Orr et al., 2005). Furthermore, anthropogenic $\mathrm{CO}_{2}$ is not evenly distributed among the ocean basins. In particular, the North Atlantic Ocean stores about $23 \%$ of anthropogenic $\mathrm{CO}_{2}$ despite representing only $15 \%$ of the global ocean area (Sabine et al., 2004). Consequently, the North Atlantic Basin, compared to other regions, might be more susceptible to ocean acidification. In situ measurements of surface ocean $\mathrm{pH}$ are rare prior to about 1990 (Byrne et al., 2010; Dore et al., 2009), however, instrumental data show that the surface global ocean $\mathrm{pH}$ has decreased by approximately $0.05 \mathrm{pH}$ units in the last 20-25 years (IPCC, 2013). Time-series data from the North Pacific and the North At- 
lantic oceans indicate that the surface ocean $\mathrm{pH}$ has been changing between -0.0015 and $-0.0024 \mathrm{pH}$ units per year (IPCC, 2013; Vázquez-Rodríguez et al., 2012).

This global rise in atmospheric $\mathrm{CO}_{2}$ has resulted in changes in surface ocean $\mathrm{pH}$ and shows a projected persistence in the near future. Therefore, proxy records from the geologic record sensitive to oceanic carbon dynamics are highly desired to place modern $\mathrm{pH}$ trends into context (e.g., Hönisch et al., 2012.). Biogenic proxy archives calcifying within the surface waters of the global oceans have the unique potential to reveal spatial and temporal patterns and trends in $\mathrm{pH}$ using boron isotopes (e.g., Anagnostou et al., 2012; Shinjo et al., 2013). However, in the dynamic coastal regions of the global ocean, local and regional processes have the potential to complicate the boron-pH proxy (described in detail below). Freshwater mixing has the potential to change (1) temperature, salinity, and $\mathrm{pH}$; (2) nutrient availability and productivity leading to changes in $\mathrm{pH}$; and (3) local seawater boron isotopic composition. Additionally, potential speciesspecific biological effects that occur during calcification need to be evaluated. Here we apply multiple isotope systems to evaluate the boron-pH proxy in the northern North Atlantic coastal and shelf-dwelling marine bivalve Arctica islandica (A. islandica) exposed to ambient conditions. We use radiogenic strontium isotopes to assess terrestrial river water influence on seawater and shell geochemistry for elements with long residence times in coastal water, such as boron. We utilize stable strontium isotopes from shell material to evaluate the potential impacts of growth rates during biomineralization.

\subsection{Boron isotopes as $\mathrm{pH}$ indicators in biogenic carbonates}

Boron has two natural stable isotopes, ${ }^{10} \mathrm{~B}$ and ${ }^{11} \mathrm{~B}$, which comprise 19.9(7) \% and 80.1(7)\% of total boron, respectively (Berglund and Wieser, 2011). The dominant aqueous species of boron in seawater are $\mathrm{B}(\mathrm{OH})_{3}$ and $\mathrm{B}(\mathrm{OH})_{4}^{-}$. The relative proportion of these two species in an aqueous environment is a function of $\mathrm{pH}$ with the following relationship:

$\mathrm{B}(\mathrm{OH})_{3}+\mathrm{H}_{2} \mathrm{O} \rightleftharpoons \mathrm{B}(\mathrm{OH})_{4}^{-}+\mathrm{H}^{+}$.

At low $\mathrm{pH}$, boron exists as $\mathrm{B}(\mathrm{OH})_{3}$ in solution, conversely, at high $\mathrm{pH}$, boron exists as $\mathrm{B}(\mathrm{OH})_{4}^{-}$. The governing reaction for isotope exchange between these two species is

${ }^{10} \mathrm{~B}(\mathrm{OH})_{3}+{ }^{11} \mathrm{~B}(\mathrm{OH})_{4}^{-} \rightleftharpoons{ }^{11} \mathrm{~B}(\mathrm{OH})_{3}+{ }^{10} \mathrm{~B}(\mathrm{OH})_{4}^{-}$.

The stable isotope ${ }^{11} \mathrm{~B}$ is enriched in $\mathrm{B}(\mathrm{OH})_{3}$ compared to $\mathrm{B}(\mathrm{OH})_{4}^{-}$, and the combination of Eqs. (1) and (2) can be used to determine the distribution of the two boron species and the isotopic composition of each for a given $\mathrm{pH}$. The isotopic composition of boron is generally reported as $\delta^{11} \mathrm{~B}=\left[\frac{\left({ }^{11} \mathrm{~B} /{ }^{10} \mathrm{~B}\right)_{\text {sample }}}{\left({ }^{11} \mathrm{~B} /{ }^{10} \mathrm{~B}\right)_{\text {SRM 951a }}}-1\right] \times 1000(\% o)$,

where SRM 951a is the internationally recognized boron isotope standard. Because the residence time of seawater boron is approximately 14 million years (Lemarchand et al., 2000), boron isotopic composition in the open ocean is considered constant over this time period, with an average seawater $\delta^{11} \mathrm{~B}$ value of $39.61 \%$ (Foster et al., 2010). Therefore, $\delta^{11} \mathrm{~B}$ has the following relationship: at low $\mathrm{pH}$, the isotopic composition of $\mathrm{B}(\mathrm{OH})_{3}$ is equal to the isotopic composition of the total dissolved boron $(39.61 \%$ ). In contrast, at high $\mathrm{pH}$, the isotopic composition of $\mathrm{B}(\mathrm{OH})_{4}^{-}$is equal to the isotopic composition of the total dissolved boron. Therefore the $\delta^{11} \mathrm{~B}$ is enriched in $\mathrm{B}(\mathrm{OH})_{3}$ by about $20 \%$ with respect to $\mathrm{B}(\mathrm{OH})_{4}^{-}$ at any equilibrium $\mathrm{pH}$ based on a constant fractionation factor.

During growth, it is assumed that marine carbonates primarily incorporate $\mathrm{B}(\mathrm{OH})_{4}^{-}$into the carbonate structure. Building on these relationships, seawater $\mathrm{pH}$ dictates the amount of $\mathrm{B}(\mathrm{OH})_{4}^{-}$in seawater and thus the isotopic composition of boron in marine carbonates. The possibility of trigonal $\mathrm{B}(\mathrm{OH})_{3}$ incorporation in carbonates, especially in calcite, is still under debate (Klochko et al., 2009; RollionBard et al., 2011a); however, after thorough calibration in targeted marine carbonate species, the $\delta^{11} \mathrm{~B}$ to $\mathrm{pH}$ transfer function can be applied. Changes in the $\delta^{11} \mathrm{~B}$ composition of shell carbonates are based on the equation

$\mathrm{pH}=p K_{\mathrm{b}}-\log \left(\frac{\delta^{11} \mathrm{~B}_{\mathrm{sw}}-\delta^{11} \mathrm{~B}_{\text {carbonate }}}{\alpha \delta^{11} \mathrm{~B}_{\text {carbonate }}-\delta^{11} \mathrm{~B}_{\mathrm{sw}}+1000(\alpha-1)}\right)$,

where $p K_{\mathrm{b}}$ is the $p K$ value for boric acid at a given temperature and salinity, and is 8.5975 at $25^{\circ} \mathrm{C}$ and $35 \mathrm{PSU}$ salinity (DOE, 1994), $\delta^{11} \mathrm{~B}_{\mathrm{sw}}$ is the isotopic composition of seawater, and $\alpha$ is the equilibrium isotopic fractionation factor between boric acid and borate ion $\left(\alpha \equiv \frac{\left({ }^{11} \mathrm{~B} /{ }^{10} \mathrm{~B}\right)_{\mathrm{B}(\mathrm{OH})_{3}}}{\left({ }^{11} \mathrm{~B} /{ }^{10} \mathrm{~B}\right)_{\mathrm{B}(\mathrm{OH})_{4}^{-}}}\right)$. Of these variables, only the seawater composition can be considered known and constant for all geographic locations and carbonate-precipitating species. Temperature, salinity and the fractionation factor must be estimated. Two empirical and analytical values of $\alpha$ are suggested for seawater: (1) $\alpha=1.0194$, a theoretical result of Kakihana et al. (1977), which has been applied widely on paleoreconstructions (Hönisch et al., 2004; Sanyal et al., 1995); and (2) $\alpha=1.0272$, which was empirically obtained from Klochko et al. (2006) and is considered to better describe the distribution of the two boron species in nature today (Foster, 2008; Rollion-Bard et al., 2011b; Rollion-Bard and Erez, 2010). Recent work of Nir et al. (2015), using reverse osmosis membranes under controlled $\mathrm{pH}$, also suggests a higher fractionation factor than the theoretical result from Kakihana et al. (1977). However, due to the ability of calcifying organisms to buffer their own local environments, speciesspecific fractionation factors and transfer functions are likely 
more appropriate than theoretical $\alpha$ values (Anagnostou et al., 2012; Hönisch et al., 2004; Krief et al., 2010; Rae et al., 2011; Reynaud et al., 2004, 2008; Trotter et al., 2011). Thus far, the $\mathrm{pH}-\delta^{11} \mathrm{~B}$ relationship has been tested extensively on some biogenic marine carbonates, primarily foraminifera and coral records, with broad success (Anagnostou et al., 2012; Henehan et al., 2013; Hönisch et al., 2004; Ni et al., 2007; Rae et al., 2011; Reynaud et al., 2004); a few measurements have been made on calcite shells (Heinemann et al., 2012; Penman et al., 2012), but no published data exist for aragonitic bivalves.

As indicated earlier, one of the primary assumptions in applying the boron isotope/pH proxy technique is that the boron isotopic composition of the seawater from which the biogenic carbonates form remains constant. Therefore, in order to use such a proxy to understand $\mathrm{pH}$ changes through the geological past, a technique is required to evaluate variability in local seawater geochemistry.

\subsection{Radiogenic strontium isotopes as a water mass tracer}

To evaluate the potential impacts of freshwater on local or regional ocean chemistry, it is necessary to differentiate sources that influence the chemical composition of the target water mass. This is especially important in coastal regions where freshwater input from river, surface runoff and/or groundwater mix with seawater often modifying both physical (e.g., temperature, salinity and/or turbidity) and chemical (e.g., nutrients, trace metal and/or isotopic compositions) conditions. Even for isotopic systems with long residence times in seawater (including boron), observations indicate that large fluxes of freshwater can cause substantial variations in coastal environments where conservative mixing behavior is generally assumed but not always achieved (Chung et al., 2009; D’Olivo et al., 2015; Huang and You, 2007; Huang et al., 2011; Widerlund and Andersson, 2006).

Radiogenic strontium has successfully been used to trace unique water masses. There are four naturally occurring isotopes of strontium: ${ }^{84} \mathrm{Sr},{ }^{86} \mathrm{Sr},{ }^{87} \mathrm{Sr}$ and ${ }^{88} \mathrm{Sr}$, with the only radiogenic isotope being ${ }^{87} \mathrm{Sr}$, which decays from ${ }^{87} \mathrm{Rb}$. Therefore, the ${ }^{87} \mathrm{Sr} /{ }^{86} \mathrm{Sr}$ ratio is widely used to trace provenance in geological studies (Aarons et al., 2013; Bataille and Bowen, 2012; Huang and You, 2007; Jahn et al., 2001). Because the residence time of $\mathrm{Sr}$ in seawater is more than 4 million years, shorter but comparable to the residence time of boron (Broecker, 1963; Goldberg, 1963), ${ }^{87} \mathrm{Sr} /{ }^{86} \mathrm{Sr}$ is considered spatially homogeneous in seawater at any instant of geological time. However, in coastal areas, radiogenic Sr isotopes vary as inputs from continental sources are released from terrestrial sediments to freshwater and then exported to the open ocean (Huang et al., 2011). The variability in ${ }^{87} \mathrm{Sr} /{ }^{86} \mathrm{Sr}$ ratios in natural archives on seasonal and annual timescales has been used as a proxy for quantitatively evaluating proportions of different water mass sources in coastal regions
(Huang et al., 2011). The similarity of residence times of $\mathrm{Sr}$ and $\mathrm{B}$ in the ocean, and potential large differences between ocean and terrestrial isotopic compositions, suggests that the radiogenic strontium composition of shell material can be used to determine if there is a potential offset between local seawater and open-ocean B isotopic composition.

Prior studies have shown that bivalve shells record both ambient seawater composition and mixing of water sources in the ambient seawater. Widerlund and Anderson (Widerlund and Andersson, 2006) developed a two-endmember mixing model of terrestrial fluvial water and seawater radiogenic $\mathrm{Sr}$ in the Baltic Sea and compared the modern bivalve ${ }^{87} \mathrm{Sr} /{ }^{86} \mathrm{Sr}$ inferred salinity across the Baltic Sea from inland to the Atlantic coast to the in situ measurements of water salinity. Their results indicate conservative characteristics of ${ }^{87} \mathrm{Sr} /{ }^{86} \mathrm{Sr}$ vs. salinity in the Baltic Sea. Maurer et al. (2012) also measured the ${ }^{87} \mathrm{Sr} /{ }^{86} \mathrm{Sr}$ ratio in a freshwater bivalve species: the $\mathrm{Sr}$ isotopic ratios recorded in the shells, in both early and late ontogeny ages, agreed with local water samples, indicating their usefulness in investigating the effects of anthropogenic contamination in rivers.

\subsection{Stable strontium isotopes in biogenic carbonates}

In addition to ${ }^{87} \mathrm{Sr} /{ }^{86} \mathrm{Sr}$, the stable isotopes of $\mathrm{Sr}\left(\delta^{88 / 86} \mathrm{Sr}\right.$, the deviation in ${ }^{88} \mathrm{Sr} /{ }^{86} \mathrm{Sr}$ of a sample relative to a standard given in parts per mil) in natural archives can serve as a means to evaluate potential vital effects linked to growth rates and metabolic processes, although the applicability is less well established and still controversial. Previously reported $\delta^{88 / 86} \mathrm{Sr}$ values of coral, foraminifera and coccolithophores from the literature show ${ }^{88} \mathrm{Sr}$ depleted results compared to the $\delta^{88 / 86} \mathrm{Sr}$ value in seawater, which suggest the lighter ${ }^{86} \mathrm{Sr}$ is preferentially incorporated into biogenic carbonates (Böhm et al., 2012; Fietzke and Eisenhauer, 2006; Krabbenhöft et al., 2010; Rüggeberg et al., 2008; Stevenson et al., 2014). If the fractionation of stable $\mathrm{Sr}$ isotopes in precipitated biogenic carbonates is dominated by kinetic isotope effects and not under equilibrium conditions, the $\delta^{88 / 86} \mathrm{Sr}$ ratio would likely have a strong correlation with precipitation temperature and/or precipitation rate. As an environmental proxy, ${ }^{88} \mathrm{Sr} /{ }^{86} \mathrm{Sr}$ in both deep sea and tropical corals has been reported as a temperature proxy (Fietzke and Eisenhauer, 2006; Rüggeberg et al., 2008). However, more recent, higher precision work, has indicated either a null relationship (foraminifera) or negative relationship (coccolithophore) between $\delta^{88 / 86} \mathrm{Sr}$ and ambient seawater temperature, suggesting growth rate controls the uptake of $\mathrm{Sr}$ isotopes into biogenic carbonates (Böhm et al., 2012; Stevenson et al., 2014). Although stable strontium applications are in their infancy, the potential for vital effects, such as growth rates, impacting stable Sr incorporation indicates it could be useful for assessing vital effects during calcification in bivalve archives. 


\subsection{The biogenic archive Arctica islandica}

The long-lived bivalve mollusk $A$. islandica, common in the shelf seas of the temperate to subpolar North Atlantic Ocean, is an excellent high-resolution marine archive with a huge potential for monitoring $\mathrm{pH}$ as well as other seawater properties (for a recent review, see Schöne et al., 2013). This stationary benthic clam lives in water depths ranging from $\sim 10 \mathrm{~m}$ to as deep as $500 \mathrm{~m}$ and thrives in full marine conditions yet can also tolerate salinities as low as 28 PSU for short time intervals (Merrill and Ropes, 1968; Nicol, 1951). Arctica islandica lives within the sediment and extends its relatively short siphons into the main water column, exchanging water to feed and remove waste. Weidman (1995) demonstrated that the geochemical signature in the shell material reflects that of the ambient water conditions and not pore water. Arctica islandica is highly suitable for environmental and ocean studies because (1) A. islandica is extremely long-lived - up to 5 centuries (Butler et al., 2013; Schöne et al., 2005; Wanamaker Jr. et al., 2008a); (2) it produces annual growth increments in its shell (Jones, 1980); (3) regional increment series can be crossdated, demonstrating a common response to environmental forcing(s) (Schöne et al., 2003); (4) fossil shells can be crossdated and floating shell chronologies can be constructed after radiocarbon dating (Scourse et al., 2006); (5) live-caught shells can be crossdated with fossil shells to assemble very long, absolutely dated growth records (Butler et al., 2009, 2011; Marchitto et al., 2000); (6) master shell chronologies can be created that are as statistically robust as tree ring chronologies (Butler et al., 2010); (7) it precipitates its aragonite shell in oxygen isotope equilibrium with ambient seawater (Weidman et al., 1994); and (8) the geochemical signature (e.g., $\left.{ }^{14} \mathrm{C}, \delta^{18} \mathrm{O}, \delta^{13} \mathrm{C}\right)$ from shell material has been used to reconstruct ocean circulation, hydrographic changes, seasonal changes in ocean conditions, and ecosystem dynamics (Butler et al., 2009; Schöne et al., 2005, 2011a; Scourse et al., 2012; Wanamaker Jr. et al., 2008a, b, 2009, 2011, 2012; Weidman and Jones, 1993; Weidman et al., 1994; Witbaard and Bergman, 2003). Despite the potential as environmental proxies, applications of non-traditional isotopic systems $\left(\delta^{11} \mathrm{~B}\right.$ and $\left.\delta^{88 / 86} \mathrm{Sr}\right)$ that have the capacity to reveal additional oceanographic and environmental information have not been explored fully.

\section{Methods}

\subsection{Sample preparation}

Living shells from the Gulf of Maine (GoM) were collected from Jonesport, Maine, USA, on 21 November 2009 with a commercial quahog-fishing vessel, F.V. Three of A Kind. The live-caught animals were then transported to the Darling Marine Center (University of Maine) in Walpole, Maine, USA, for the culture experiment. Seawater was pumped from the Damariscotta River estuary from $\sim 10 \mathrm{~m}$ and delivered to the flowing seawater laboratories. The shells were reared in flow-through seawater tanks without filtration, in which the temperature, salinity and seawater $\mathrm{pH}$ were monitored in situ concurrently and continuously (Fig. 1d). The pH of the culture seawater was also measured a total of 7 times with a highly accurate Metrohm handheld $\mathrm{pH}$ meter $( \pm 0.003$ units). Additional details of the culture conditions are given in Beirne et al. (2012). Tank seawater was sampled biweekly throughout the culture period and filtered through a $0.45 \mu \mathrm{m}$ filter. Two additional samples, one from the Gulf of Maine surface seawater and one from auxiliary water flow pumped into the culture tanks, were also sampled to evaluate if the culture experiment was representative of the natural marine environment. Boron isotopic data from seawater samples during the experiment were previously measured and published by Liu et al. (2013).

Shell subsamples were collected at Iowa State University via a Dremel hand drill, with 10 intervals throughout the 8month culturing (Fig. 1c). Based on the calcein staining (see Beirne et al., 2012, for details) and natural marking on the external shell, the timing of the winter (January-March), spring (March-May), and summer (May-August) growing seasons were evident (Fig. 1a-c). These markings were used to establish growth rates during each season as well as to provide temporal controls on the sampled shell material. The instrumental data and shell growth-rates have been published by Beirne et al. (2012), and the average seawater salinity, temperature, and $\mathrm{pH}$ for shell record comparison are summarized in Table 1.

The boron and strontium concentrations in A. islandica shells are about 10 and $1000 \mathrm{ppm}$, respectively (Zhang, 2009); $1 \mathrm{mg}$ of shell material, after cleaning (details noted below), is required for B (Liu et al., 2013) and $\mathrm{Sr}$ (Stevenson et al., 2014) isotopic measurements. Because shell growth rates differ throughout the year, and throughout ontogeny (Beirne et al., 2012), we have one subsample from January to March, but we have four subsamples from March to May and five subsamples from May to August.

The subsample cleaning procedure was modified from Barker et al. (2003). In summary, coral and shell powders were first cleaned with Super-Q (SQ) water (Millipore, $>18.2 \mathrm{M} \Omega$ ) in an ultrasonic bath 3 times and the suspension solution was extracted after centrifuging. Samples were then treated with $10 \% \mathrm{H}_{2} \mathrm{O}_{2}$ at room temperature overnight to remove organic particles embedded in skeletons. The samples were rinsed with SQ water, $0.001 \mathrm{~N} \mathrm{HNO}_{3}$ and SQ water again. After drying at $60^{\circ} \mathrm{C}$, samples were weighed and then dissolved in $\sim 1.7 \mathrm{~N} \mathrm{HCl}$ with a boron concentration equal to about $750 \mathrm{ppb}$.

Seawater samples were diluted to $[\mathrm{B}]=\sim 750 \mathrm{ppb}$ in $1.7 \mathrm{~N}$ $\mathrm{HCl}$ for boron measurements. Because the strontium concentration in seawater is about 9 ppm, the residual after sublimation (see below) is not enough for strontium isotope measurements. Therefore, for strontium isotope analysis of seawater, 


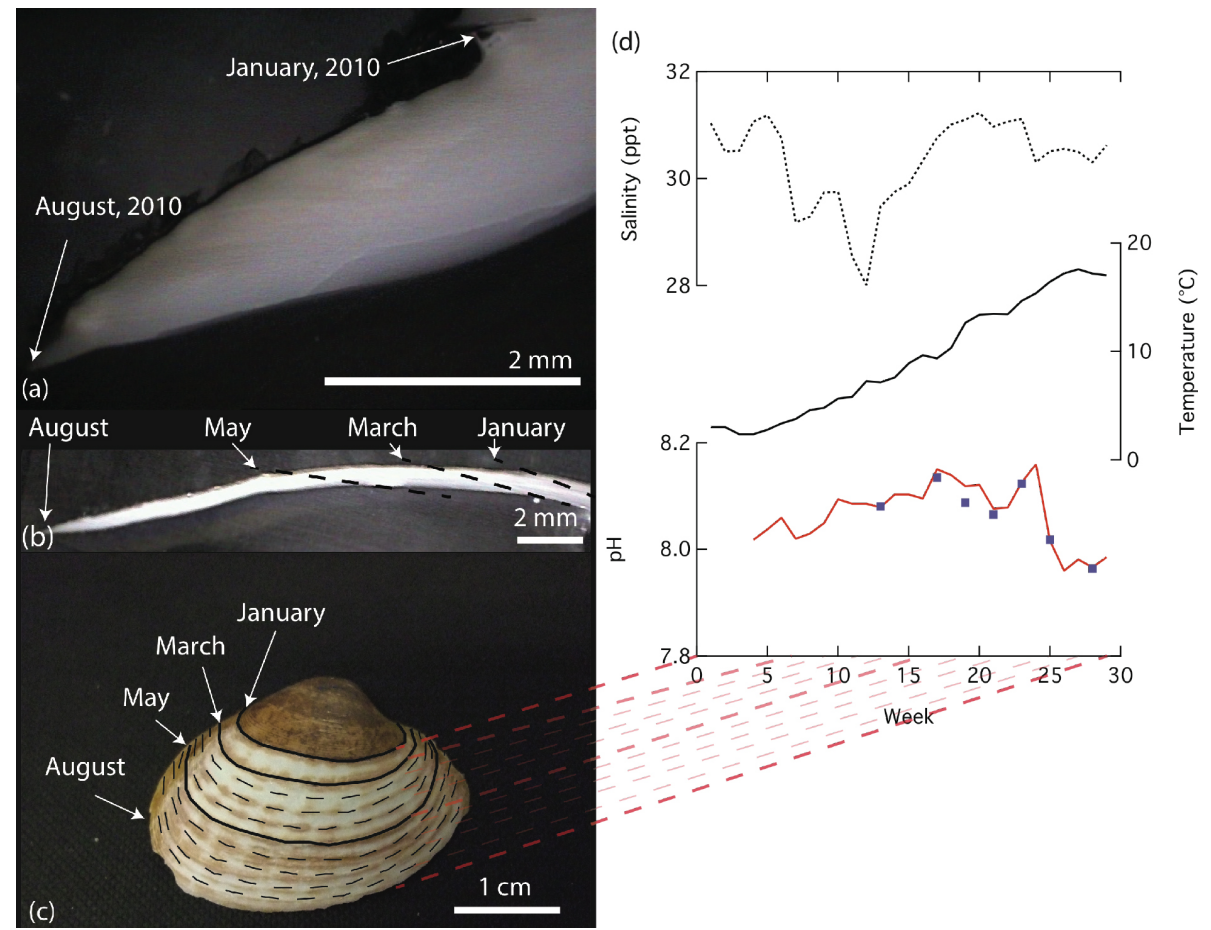

Figure 1. Photos of (a) adult and (b, c) juvenile A. islandica from the culture experiment. External marks on the shell or calcein marks in the cross section were used to constrain shell growth. (d) shows the corresponding in situ measurements of tank water salinity, temperature and pH during the 31-week culture experiment. The juvenile shells were sampled in 10 intervals for this study (c). Note that because the growth rates differ during the season, each interval represents different time durations $(\mathbf{c}, \mathbf{d})$.

an additional $100 \mu \mathrm{L}$ of seawater sample was dried and redissolved in concentrated $\mathrm{HNO}_{3} 3$ times and brought into solution in $7 \mathrm{~N} \mathrm{HNO}_{3}$ for column chemistry. Spiked samples were mixed to have a sample to spike ratio of $1: 1$, with at least $600 \mathrm{ng}$ of sample $\mathrm{Sr}$ in solution prior to preconditioning steps.

Separation of the boron and strontium elemental fractions was achieved using a combination of microsublimation (Liu et al., 2013) and elemental specific ion exchange resin. Briefly, $<50 \mu \mathrm{L}$ of sample solution was loaded in the cap of a conic-bottom vial in an up-side-down position and put into the high-throughput system. After $12 \mathrm{~h}$ of sublimation at $70-74{ }^{\circ} \mathrm{C}$, the purified boron sample solution is condensed and collected on the conic tip. To further improve the reproducibility for carbonate samples, an extra $2 \mu \mathrm{L}$ of $30 \% \mathrm{H}_{2} \mathrm{O}_{2}$ was added to the purified solution $(\sim 90 \%$ of the volume before sublimation) for all the runs after 23 April 2014. The sample solution was left stagnant in the vial, and the cap of the conic vial was then loosened for $2 \mathrm{~h}$ to reduce the organic levels and to liberate oxygen gas. The microsublimation method only extracts boron from the sample solution; therefore, the residual on the cap of the vials is reserved for $\mathrm{Sr}$ separation and analysis.
All measurements were conducted on a Thermo Fisher Triton PLUS multicollector thermal ionization mass spectrometer operating in positive ion mode for strontium isotope analysis and negative ion mode for boron isotope analysis at the Glaciochemistry and Isotope Geochemistry Lab (GIGL) at the Department of Earth and Environmental Sciences, University of Michigan.

\subsection{Radiogenic and stable strontium isotope analysis}

\subsubsection{General}

The residuals of carbonate samples after sublimation were redissolved in concentrated $\mathrm{HNO}_{3}$ to $[\mathrm{Sr}]=\sim 10 \mathrm{ppm}$, which is approximately the same $\mathrm{Sr}$ concentration in seawater. A small aliquot of sample was spiked with our ${ }^{84} \mathrm{Sr}-{ }^{87} \mathrm{Sr}$ double-spike solution. Both unspiked normal sample and spiked mixture sample solutions were then dried down 3 times and then dissolved in $7 \mathrm{~N} \mathrm{HNO}_{3}$ for $\mathrm{Sr}$ column chemistry. In order to separate strontium element from the matrix, samples were passed through a $50-100 \mu \mathrm{m} \mathrm{Sr-spec} \mathrm{resin}$ (Eichrom), and $0.035 \mathrm{~N} \mathrm{HNO}_{3}$ was used to elute $\mathrm{Sr}$ after using $7 \mathrm{~N} \mathrm{HNO}_{3}$ to elute the others. The eluted $\mathrm{Sr}$ aliquots were refluxed with $30 \% \mathrm{H}_{2} \mathrm{O}_{2}$ overnight, dried, and finally dissolved in concentrated $\mathrm{HNO}_{3}$ for loading (Liu, 2010). 
Table 1. Summary of in situ instrumental data of tank seawater salinity, temperature, and $\mathrm{pH}$ during culture season.

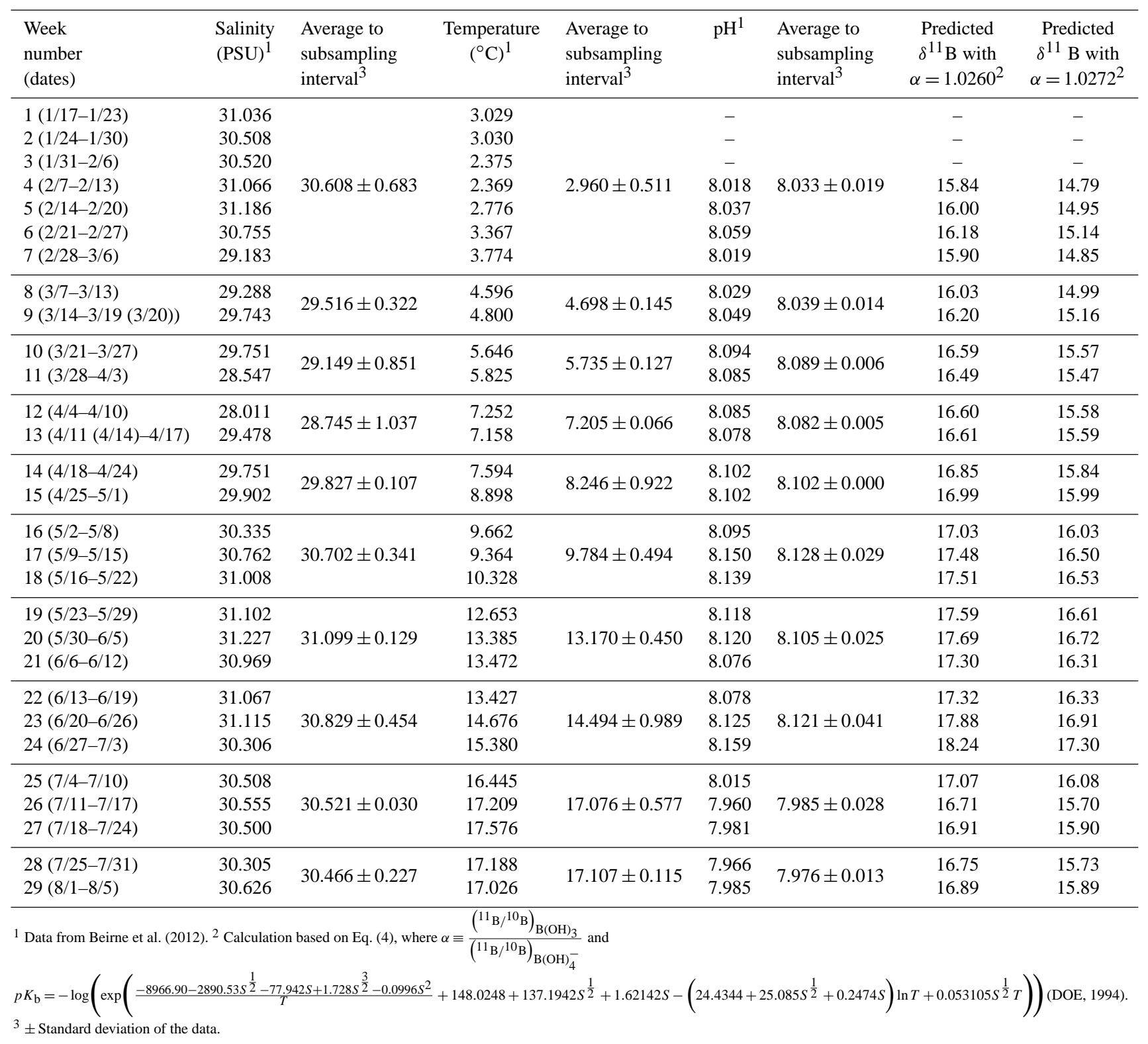

For radiogenic isotopic measurements, 100-200 ng of $\mathrm{Sr}$ sample was loaded onto outgassed Re filaments with $\mathrm{TaF}_{5}$ activator solution. Each sample was heated to an intensity of $\sim 8 \mathrm{~V}^{88} \mathrm{Sr}$. A total of 400 cycles of data were collected for each measurement to determine the $\mathrm{Sr}$ isotopic ratios with within run precision better than 10 ppm (2 SE). Mass 84-86 were detected with five Faraday cups positioned from L1 to $\mathrm{H} 3$, respectively, with ${ }^{85} \mathrm{Rb}$ measured in the center cup. The long-term reproducibility of ${ }^{87} \mathrm{Sr} /{ }^{86} \mathrm{Sr}$ for SRM987 $\mathrm{Sr}$ standard was $0.710268 \pm 21(2 \sigma, n=140)$ from the time of Triton installation in January 2012 to April 2014. In May 2014, problems associated with the H3 Faraday cup resulted in change to a ${ }^{86} \mathrm{Sr}$-centered cup configuration (June to Oc- tober 2014). After $\mathrm{H} 3$ cup replacement, the ${ }^{85} \mathrm{Rb}$-centered cup configuration was established again. The new SRM987 ${ }^{87} \mathrm{Sr} /{ }^{86} \mathrm{Sr}$ average value is $0.719246 \pm 13(2 \sigma, n=42)$ for data collected after June 2014 (for both cup configurations) and sample data were normalized based on this new SRM987 standard ratio. The reported ${ }^{87} \mathrm{Sr} /{ }^{86} \mathrm{Sr}$ data in this study were all normalized to SRM987 $=0.710250$ for inter-laboratory comparisons.

\subsubsection{Double spike (84-87) Sr}

High precision ${ }^{88} \mathrm{Sr} /{ }^{86} \mathrm{Sr}$ isotopic compositions are measured by double spike (DS); measurements by DS remove instrumental mass bias associated with thermal ionization 


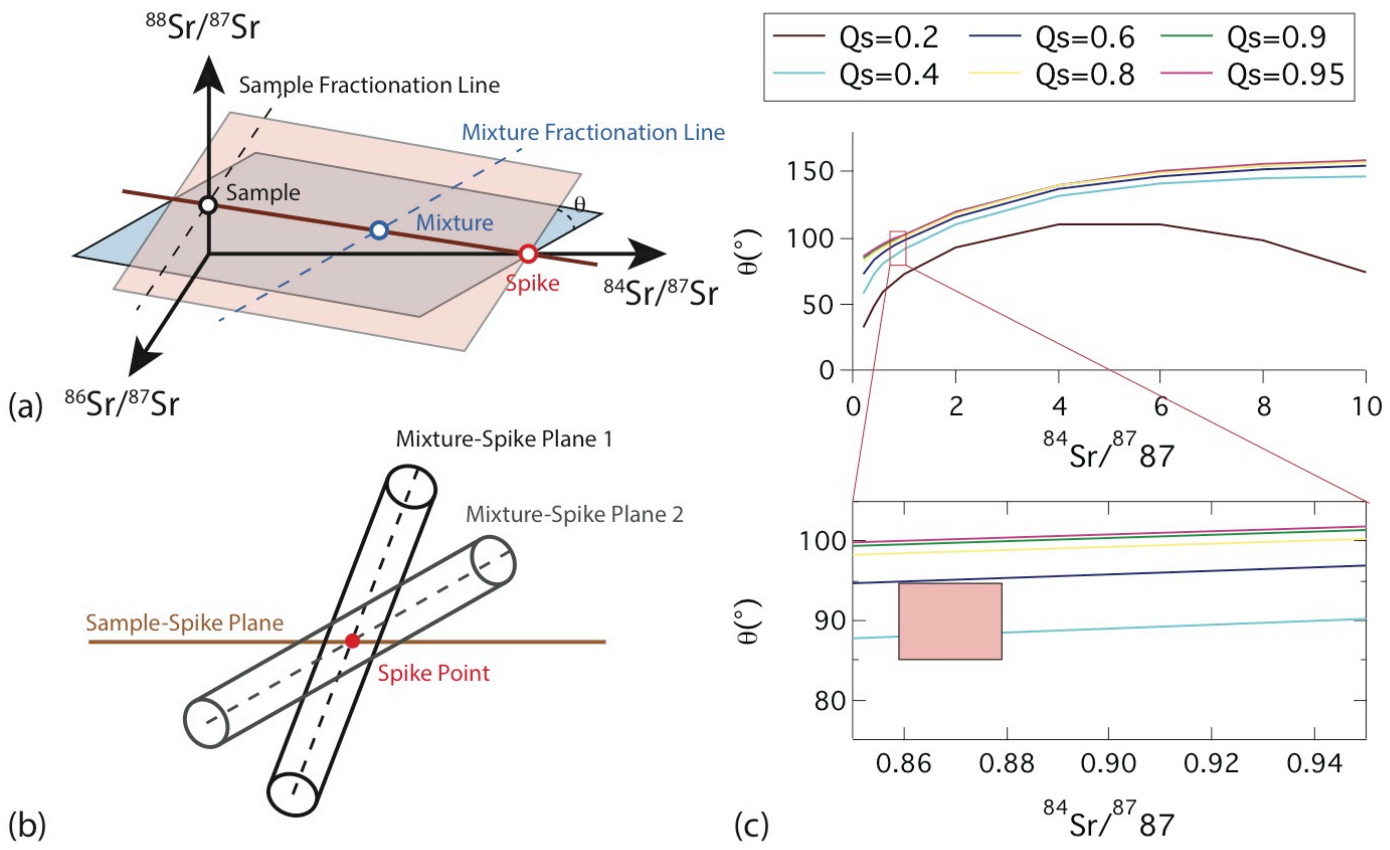

Figure 2. The illustrations of (a) the 84-87 Sr double-spike method, (b) how the angle between mixture-spike plane and sample-spike plane can influence the precision of the deconvolved result, and (c) the optimal sample-spike ratio in our study.

during sample runs. The double-spike method was first developed in the 1960s: Dodson (1963) outlined a methodology for determining the unknown mass discrimination factor directly if the sample is mixed with a double spike, consisting of an enriched mixture of two stable isotopes. Later, Krogh (1964) worked out a graphical method for a spike enriched in both ${ }^{84} \mathrm{Sr}$ and ${ }^{86} \mathrm{Sr}$. Finally, Long (1966) showed that the correction factor for mass discrimination can be calculated by using three elements and depends on the fractional abundances in the normal and spike elements. A simpler expression was then published by Boelrijk (1968). These pioneering studies founded the basis of the $\mathrm{Sr}$ double-spike method, and $\mathrm{Sr}$ double spikes have already been successfully used to determine the $\mathrm{Sr}$ isotopic composition of the early solar system (Patchett, 1980a, b). Optimal spike compositions are determined using a 3-D data reduction method (Galer, 1999). The choice of isotope ratios used in the equations, the mathematical formulation to solve for the mass discrimination factor $\varepsilon$ and the influence of the spike-to-sample ratio in the mixture should be taken into consideration. With the addition of "tuning" with IAPSO (International Association for the Physical Sciences of the Oceans) seawater standards (Krabbenhöft et al., 2009), this double-spike method could produce more precise true isotopic compositions in an unknown sample solution.

A ${ }^{84} \mathrm{Sr}-{ }^{87} \mathrm{Sr}$ double-spike solution was prepared at GIGL at the University of Michigan following the method from Liu (2010). The optimal value of the spike depends on the angle of two planes, defined by normal sample $(\mathrm{N})$ fractionation line and spike point and mixture (M) fractionation line and spike point, respectively (Fig. 2), expressed as $\theta$ here. Because all the measured points have their own errors, when the angle between these two planes approximates a right angle, the intersected area reaches a minimum and, thus, the $\mathrm{N}-\mathrm{M}-\mathrm{S}$ line will be defined precisely (Fig. 2b). Therefore, by checking different portions of spike mixing with the normal sample $\left(Q_{\mathrm{s}}\right)$, mathematically, the distribution of $\theta$ to spike composition can be derived (Fig. 2c). For our ${ }^{84} \mathrm{Sr}-{ }^{87} \mathrm{Sr}$ double spike with an ${ }^{84} \mathrm{Sr} /{ }^{87} \mathrm{Sr}$ ratio of 0.8679 , the optimal $Q_{\mathrm{s}}$ is about 0.5 , which makes the two planes perpendicular to each other. Within a range of $Q_{\mathrm{s}}=0.45-0.55, \theta$ is still in a range of $\pm 2^{\circ}$, which supports a tolerance of spiking samples with a slight deviation from a 1:1 sample to spike ratio. The stable Sr data were reported as $\delta^{88 / 86} \mathrm{Sr}$, which was defined as:

$\delta^{88 / 86} \mathrm{Sr}=\left[\frac{\left({ }^{88} \mathrm{Sr} /{ }^{86} \mathrm{Sr}\right)_{\text {sample }}}{\left({ }^{88} \mathrm{Sr} /{ }^{86} \mathrm{Sr}\right)_{\text {SRM } 987}}-1\right] \times 1000(\% o)$.

In this study, a Python script was applied to evaluate true normal values of the shells. We assumed the measured isotopic ratios of normal sample and spiked mixture would follow exponential law, and the equations of each ${ }^{87} \mathrm{Sr}$-based isotopic ratio for both normal and mixture sample could be stated. After inputting the known isotopic composition of the spike, the true value of each isotope concentration can be solved using a least squares minimization of the residual of the non-linear equations.

For the spiked sample solution, 200-250 ng of Sr samples was loaded onto outgassed Re filaments with $\mathrm{TaF}_{5}$ activator solution and run the same as the unspiked sam- 


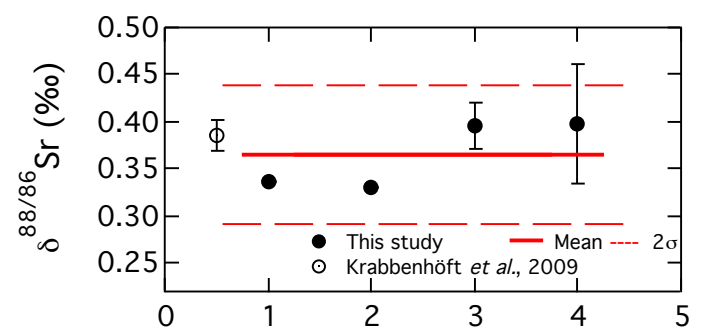

(a) IAPSO Number of samples

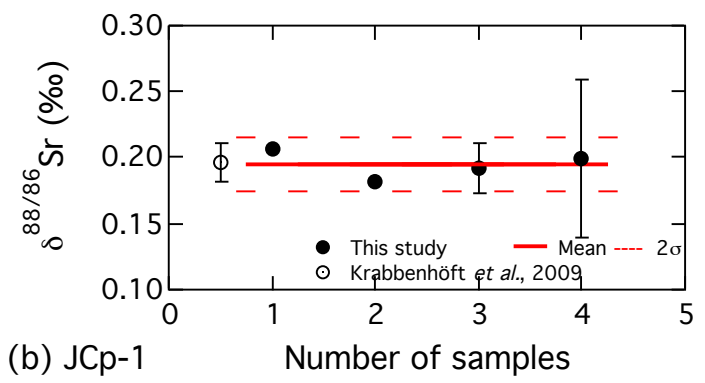

Figure 3. Stable $\mathrm{Sr}$ results for (a) seawater standard IAPSO and (b) inter-laboratory biogenic carbonate standards JCp-1.

ples described in the previous section. The deconvolved $\delta^{88 / 86} \mathrm{Sr}$ values for seawater standard IAPSO 141 and an inter-laboratory coral standard JCp- 1 are $0.390 \pm 16 \%$ o $(2 \sigma$, $n=4)$ and $0.144 \pm 26 \% \circ(2 \sigma, n=3)$, respectively. According to Krabbenhöft et al. (2009), using the IAPSO seawater standard to fine-tune the $\mathrm{Sr}$ double-spike composition provides an optimal $\delta^{88 / 86} \mathrm{Sr}$ result. Here we used the same technique and obtained a compatible $\delta^{88 / 86} \mathrm{Sr}$ value for the IAPSO seawater standard to the reported values from Krabbenhöft et al. (2009). However, due to the $\mathrm{H} 3$ cup deficiency, the deconvolved $\delta^{88 / 86} \mathrm{Sr}$ value of the inter-laboratory carbonate standard, $\mathrm{JCp}-1$ is about $0.05 \%$ lighter than the reported values between April 2014 and June 2014. This offset was fixed, with the alternate cup configuration and replacement of H3 cup, after June 2014 and new values of IAPSO $=0.365 \pm 73 \% \circ(2 \sigma, n=4)$ and JCp- $1=0.195 \pm 21 \%$ o $(2 \sigma, n=4)$ (Fig. 3$)$ were obtained.

\subsection{Boron isotope analysis}

The procedure used for obtaining B isotopic compositions by total evaporation (TE) is described in Liu et al. (2013). In summary, $1 \mu \mathrm{L}$ of boron-free synthetic seawater matrix was loaded onto outgassed single Re filament at $0.8 \mathrm{~A}$ current, followed by $1 \mu \mathrm{L}$ of sample solution with $30 \mathrm{~s}$ of waiting between the two steps. Samples were then dried down at $2 \mathrm{~A}$ current for $10 \mathrm{~s}$ and then the filaments were flashed to a dull red color in the center of the filament (about $2.5 \mathrm{~A}$ ) and ready for analysis. Data collection was initiated when the intensity of mass 42 reached $20 \mathrm{mV}$, and terminated after the signal dropped lower than the initial $20 \mathrm{mV}$.

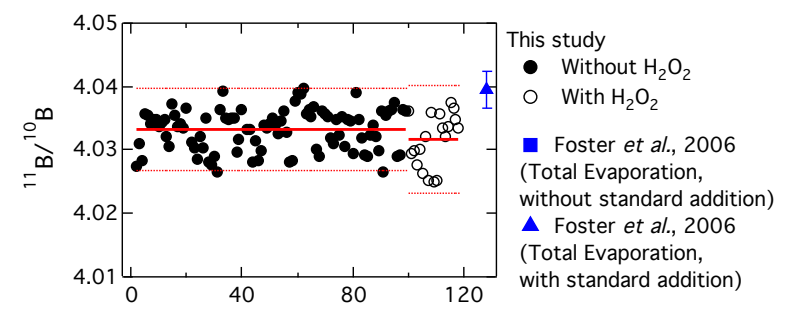

(a) SRM 951a Number of Runs
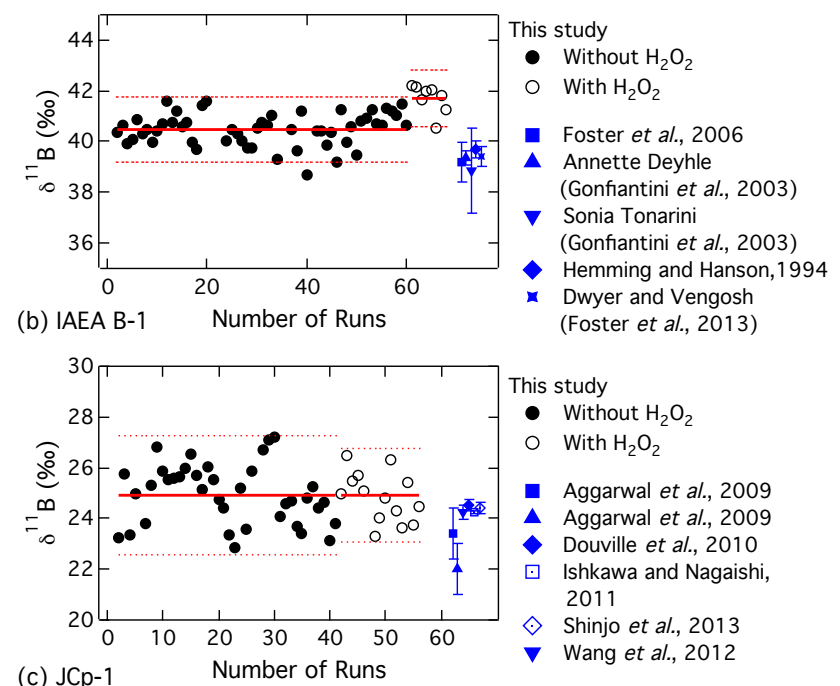

Figure 4. Long-term precision of (a) boric acid standard SRM 951a, (b) seawater standard IAEA B-1, and (c) inter-laboratory carbonate standard JCp-1.

The long-term reproducibility (18 months) of ${ }^{11} \mathrm{~B} /{ }^{10} \mathrm{~B}$ for boric acid standard SRM (standard reference material) $951 \mathrm{a}$ is $4.0332 \pm 0.0064(2 \sigma, n=97)$ before treated with $30 \% \mathrm{H}_{2} \mathrm{O}_{2}$ and is $4.0316 \pm 0.0084(2 \sigma, n=19)$ after the extra treatment. The precisions of $\delta^{11} \mathrm{~B}$ for seawater and biogenic carbonate standards without addition of peroxide are $40.46 \pm 1.29 \%$ o $(2 \sigma, n=54)$ and $24.94 \pm 2.35 \%$ o $(2 \sigma$, $n=39$ ) for IAEA B-1 and JCp-1, respectively; and $41.70 \pm 1.13 \% \circ(2 \sigma, n=8)$ and $24.93 \pm 1.83 \%$ o $(2 \sigma, n=18)$ for IAEA B-1 and JCp-1, respectively, with $\mathrm{H}_{2} \mathrm{O}_{2}$ treatment (Fig. 4).

\section{Results}

The in situ seawater salinity, temperature and $\mathrm{pH}$ results are summarized in Table 1. To compare the instrumental data to the shell records, the instrumental results were averaged with respect to the subsampling intervals. The seawater and shell results are summarized in Tables 2 and 3, respectively. 


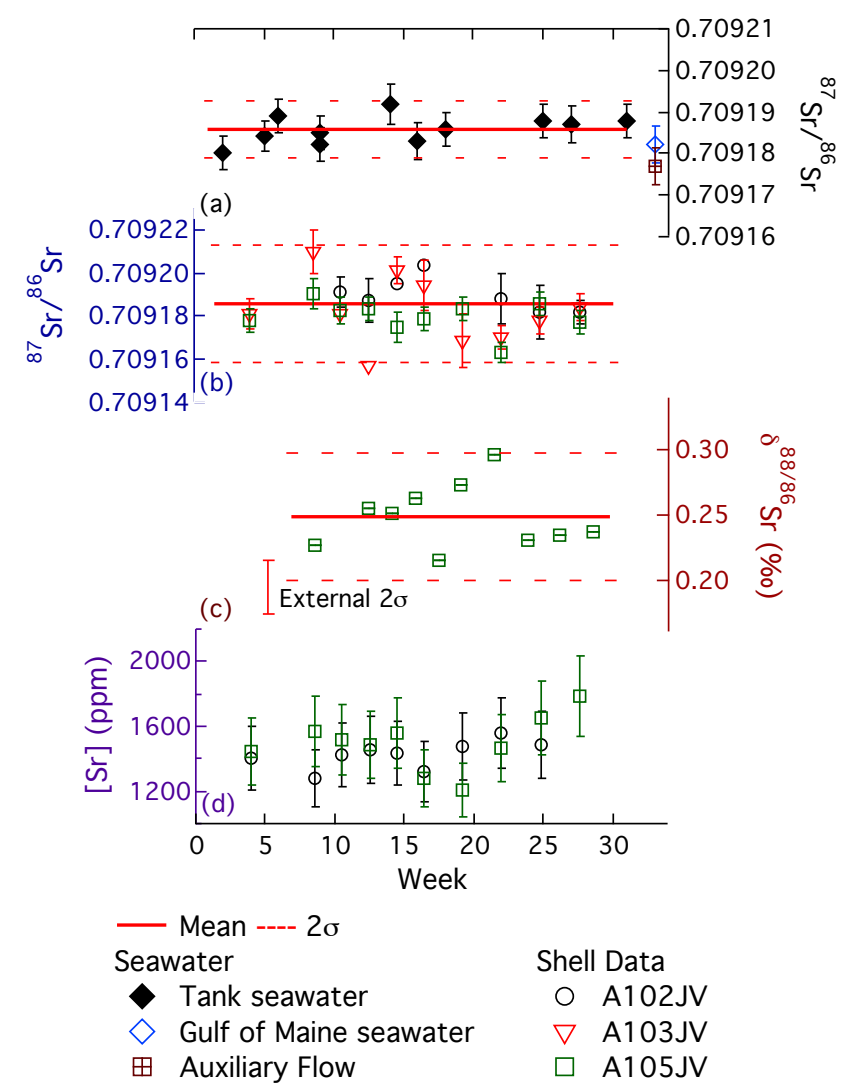

Figure 5. GoM ${ }^{87} \mathrm{Sr} /{ }^{86} \mathrm{Sr}$ data for (a) seawater samples and (b) shell samples, and the double-spike deconvolved (c) $\delta^{88 / 86} \mathrm{Sr}$ values and (d) Sr concentrations for the juvenile shell.

\section{$3.1{ }^{87} \mathrm{Sr} /{ }^{86} \mathrm{Sr}$ and $\delta^{88 / 86} \mathrm{Sr}$}

\subsection{1 ${ }^{87} \mathrm{Sr} /{ }^{86} \mathrm{Sr}$}

The ${ }^{87} \mathrm{Sr} /{ }^{86} \mathrm{Sr}$ ratios of seawater range from 0.709177 to 0.709192 , with an average of $0.709185 \pm 8(2 \sigma, n=13)$. There is no distinguishable difference between samples from offshore Gulf of Maine seawater, auxiliary flow and tank waters (Fig. 5a). For shell carbonate, the ${ }^{87} \mathrm{Sr} /{ }^{86} \mathrm{Sr}$ ratios range from 0.709163 to 0.709210 , with an average of $0.709183 \pm 23(2 \sigma, n=27)$. Both the seawater and shell ${ }^{87} \mathrm{Sr} /{ }^{86} \mathrm{Sr}$ are identical to the mean seawater values (Fig. 5a, b). Because all the radiogenic Sr results are identical within error, there is no impact from seawater salinity, seawater temperature or $\mathrm{pH}$.

\subsection{2 $\delta^{88 / 86} \mathrm{Sr}$}

Two sets of shell samples, A103JV and A105JV, were spiked for stable Sr measurements. However, due to the defect of $\mathrm{H} 3$ cup, the A103JV double-spike results are underestimated and are not listed. The deconvolved $\delta^{88 / 86} \mathrm{Sr}$ for A105JV and $\mathrm{Sr}$ concentrations values for both of A103JV and A105JV from high-resolution shell records are shown in Fig. 5c

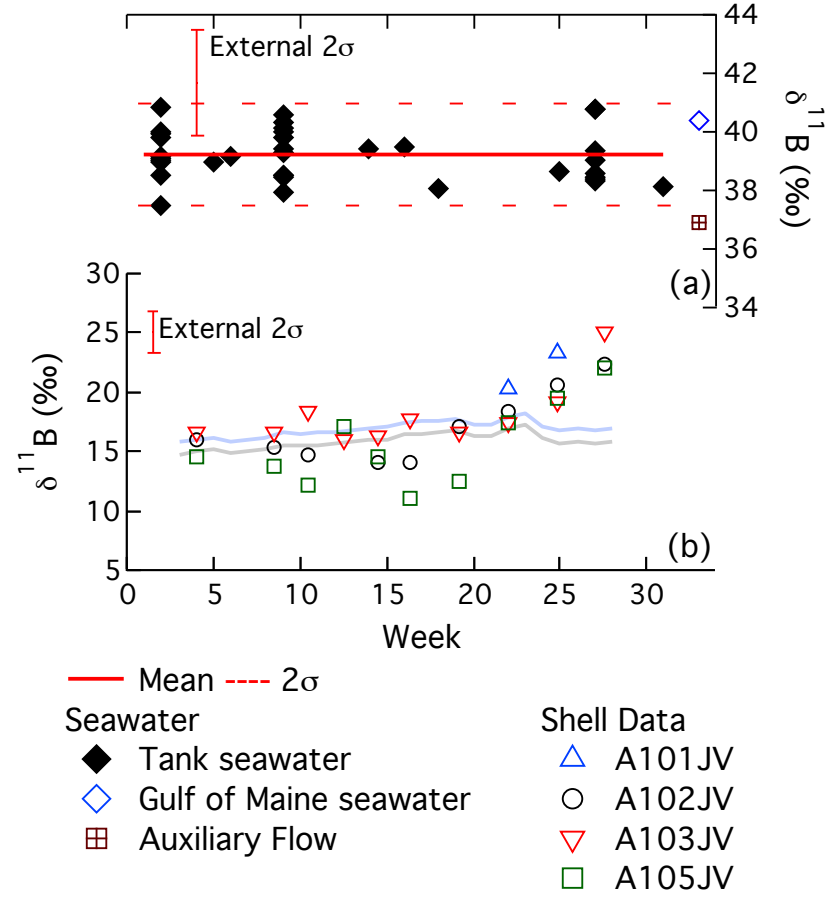

Prediction lines

$\alpha=1.0272$ (Klochko et al., 2006)

$\alpha=1.0260$ (Nir et al., 2015)

Figure 6. GoM boron data for (a) seawater samples and (b) shell samples. Two prediction lines listed were calculated based on our instrumental culture seawater $\mathrm{pH}$, temperature, and salinity data, and two boron fractionation factors: $\alpha=1.0272$ (Klochko et al., 2006) and $\alpha=1.0260$ (Nir et al., 2015), where $\alpha \equiv \frac{\left({ }^{11} \mathrm{~B} /{ }^{10} \mathrm{~B}\right)_{\mathrm{B}(\mathrm{OH})_{3}}}{\left({ }^{11} \mathrm{~B} /{ }^{10} \mathrm{~B}\right)_{\mathrm{B}(\mathrm{OH})_{4}^{-}}}$ Equation (4) was used for the calculation.

and d, respectively. The $\delta^{88 / 86} \mathrm{Sr}$ values range from 0.215 to $0.296 \%$ with an average of $0.248 \pm 48 \%$ o $(2 \sigma, n=10)$ and the concentration ranges from $1200-1800 \mathrm{ppm}$. Considering analytical uncertainty, no distinctive difference or trend for either $\mathrm{Sr}$ concentration or stable $\mathrm{Sr}$ isotopic composition in the shells is observed throughout the culture season. Similarly, no significant correlation can be found between stable $\mathrm{Sr}$ isotopes or $\mathrm{Sr}$ concentrations with any measured ambient seawater conditions.

\subsection{Boron isotopic composition $\left(\delta^{11} B\right)$ in ambient seawater, the shell and aragonite shell}

Boron isotopic compositions of 11 tank water samples are from 37.51 to to $47.83 \%$, and the average for 36 sample runs is $39.20 \pm 1.73 \%$. The $\delta^{11} \mathrm{~B}$ values for additional seawater samples from the offshore Gulf of Maine and the auxiliary flow to the culture tanks are 36.93 and and $40.38 \%$, respectively (Fig. 6a) (Liu et al., 2013). Similar to what has been observed from radiogenic $\mathrm{Sr}$ data in seawater, the boron isotopic composition of our culture seawater is invariant and 
Table 2. Summary of seawater data.

\begin{tabular}{|c|c|c|c|}
\hline Sample ID & Week & ${ }^{87} \mathrm{Sr} /{ }^{86} \mathrm{Sr}(2 \mathrm{SE})$ & $\delta^{11} \mathrm{~B}(\% \circ)$ \\
\hline Tank A 031710 & 9 & $0.709182(4)$ & 38.48 \\
\hline Tank A 041810 & 14 & $0.709192(5)$ & 39.41 \\
\hline Tank A 050810 & 16 & $0.709183(4)$ & 39.47 \\
\hline Tank A 052210 & 18 & $0.709186(4)$ & 38.04 \\
\hline Tank A 081610 & 31 & $0.709188(4)$ & 38.10 \\
\hline \multirow[t]{10}{*}{ Tank B 031910} & 9 & $0.709185(4)$ & 39.31 \\
\hline & & & 39.97 \\
\hline & & & 38.50 \\
\hline & & & 40.59 \\
\hline & & & 38.51 \\
\hline & & & 40.10 \\
\hline & & & 39.45 \\
\hline & & & 40.33 \\
\hline & & & 39.81 \\
\hline & & & 37.91 \\
\hline Flow A 021410 & 5 & $0.709184(4)$ & 39.00 \\
\hline Flow A 070510 & 25 & $0.709188(4)$ & 38.65 \\
\hline \multirow[t]{8}{*}{ Flow A 072210} & 27 & $0.709187(4)$ & 38.33 \\
\hline & & & 39.36 \\
\hline & & & 38.57 \\
\hline & & & 38.48 \\
\hline & & & 38.40 \\
\hline & & & 39.02 \\
\hline & & & 40.77 \\
\hline & & & 40.78 \\
\hline \multirow[t]{10}{*}{ Flow \#2 013010} & 2 & $0.709180(4)$ & 37.51 \\
\hline & & & 38.53 \\
\hline & & & 39.01 \\
\hline & & & 39.91 \\
\hline & & & 40.83 \\
\hline & & & 40.01 \\
\hline & & & 39.08 \\
\hline & & & 38.98 \\
\hline & & & 39.78 \\
\hline & & & 39.14 \\
\hline Flow \#2 022710 & 6 & $0.709189(4)$ & 39.16 \\
\hline Aux. & 33 & $0.709182(5)$ & 36.93 \\
\hline GoM 112309 & 33 & $0.709177(4)$ & 40.38 \\
\hline
\end{tabular}

identical to the open-ocean composition reported by Foster et al. (2010).

High-resolution boron isotopic composition records from four juvenile shells (A101JV, A102JV, A103JV and A105JV) show nearly identical patterns and trends throughout the experiment. The shell $\delta^{11} \mathrm{~B}$ values range from 11.09 to $18.81 \%$ before week 19 and from 17.41 to $25.12 \%$ after week 19 (Fig. 6b). Compared to seawater temperature and average shell growth rates in three growth seasons, we found a distinct rise in $\delta^{11} \mathrm{~B}$ for temperatures over $\sim 13{ }^{\circ} \mathrm{C}$. However, this rapid change in $\delta^{11} \mathrm{~B}$ did not correlate to the rapid change in shell growth during the culture period.

In order to evaluate the $\mathrm{pH}$ dependency of the $\delta^{11} \mathrm{~B}$, Eq. (4) is used. Based on in situ temperature, salinity and $\mathrm{pH}$ mea-

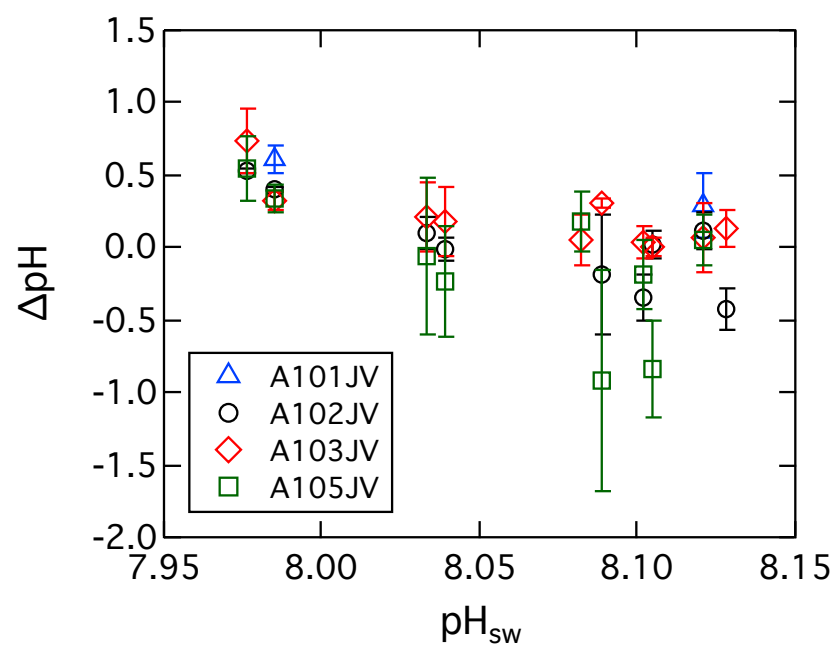

Figure 7. The calculated $\mathrm{pH}$ discrepancy $\left(\Delta \mathrm{pH}=\mathrm{pH}_{\text {shell }}-\mathrm{pH}_{\mathrm{sw}}\right)$ shows a statistically significant negative relationship to $\mathrm{pH}_{\mathrm{sw}}$ $\left(R^{2}=0.35 ; p\right.$ value $\left.\leq 0.001\right)$. The negative correlation supports the argument that $A$. islandica regulate their EPF $\mathrm{pH}$ for calcification. The shell calcification $\mathrm{pH}\left(\mathrm{pH}_{\text {shell }}\right)$ were calculated based on in situ water temperature $\alpha=1.0272$ (Klochko et al., 2006).

surements throughout the culture experiment, we calculated the predicted range in $\delta^{11} \mathrm{~B}$ of the A. islandica shell with $\alpha=1.0272$, which was empirically obtained from Klochko et al. (2006) and is considered to better describe the distribution of the two boron species in the natural system (Foster, 2008; Rollion-Bard et al., 2011b; Rollion-Bard and Erez, 2010) (Fig. 6b). Another prediction line calculated based on an independently derived fractionation factor from Nir et al. (2015) is also shown for reference (Fig. 6). The predictions suggest a slight increase in $\delta^{11} \mathrm{~B}$ throughout the culture season, primarily due to more than a $15^{\circ} \mathrm{C}$ temperature increase. A $0.2 \mathrm{pH}$ unit drop, observed between week 24 and 26 , should have decreased the $\delta^{11} \mathrm{~B}$ value by about $2 \%$ even with the large temperature change. Most of the shell $\delta^{11} \mathrm{~B}$ data followed the two prediction lines before week 19, with some of the data lower than the predictions. After week 19, the $\delta^{11} \mathrm{~B}$ data deviate significantly and trend toward higher $\delta^{11} \mathrm{~B}$ values. Duplications on different individual shells all show the same trend.

We also calculated shell $\mathrm{pH}\left(\mathrm{pH}_{\text {shell }}\right)$ with $\alpha=1.0272$ based on average tank water $\delta^{11} \mathrm{~B}$, shell $\delta^{11} \mathrm{~B}$ and the corresponding average seawater temperature and salinity values. The results show a significant negative relationship between $\Delta \mathrm{pH}$ and $\mathrm{pH}_{\mathrm{sw}}\left(R^{2}=0.35 ; p\right.$ value $\left.\leq 0.001\right)$ (Fig. 7). 
Table 3. Summary of shell data.

\begin{tabular}{|c|c|c|c|c|c|c|c|c|c|}
\hline $\begin{array}{l}\text { Sample } \\
\text { ID }\end{array}$ & $\begin{array}{l}\text { Week } \\
\text { number }\end{array}$ & $\begin{array}{l}{ }^{87} \mathrm{Sr} /{ }^{86} \mathrm{Sr} \\
(2 \mathrm{SE})\end{array}$ & $\begin{array}{c}\delta^{88 / 86} \mathrm{Sr} \\
(\% \circ)\end{array}$ & $\begin{array}{c}{[\mathrm{Sr}]} \\
(\mathrm{ppm})\end{array}$ & $\begin{array}{c}\delta^{11} \mathrm{~B} \\
(\% \circ)\end{array}$ & $\begin{array}{c}\text { Average } \\
\text { growth rate } \\
\left(\mathrm{mm}^{-1} \text { week }^{-1}\right)^{1}\end{array}$ & $\mathrm{pH}_{\text {shell }}^{2}$ & $\Delta \mathrm{pH}^{3}$ & $\begin{array}{c}2 \mathrm{SD} \text { for } \\
\text { calculated } \\
\mathrm{pH}^{4}\end{array}$ \\
\hline A101JV-8 & 22 & - & - & - & 20.32 & - & 8.419 & 0.298 & 0.22 \\
\hline A101JV-9 & 24.8 & - & - & - & 23.34 & - & 8.595 & 0.610 & 0.10 \\
\hline A102JV-1 & 4 & $0.709181(7)$ & 0.132 & 1403 & 15.68 & 0.27 & 8.139 & 0.105 & 0.11 \\
\hline A102JV-2 & 8.5 & $0.709210(10)$ & 0.151 & 1282 & 14.94 & \multirow{4}{*}{0.53} & 8.020 & -0.019 & 0.08 \\
\hline A102JV-3 & 10.5 & $0.709181(10)$ & 0.158 & 1422 & 14.28 & & 7.898 & -0.191 & 0.42 \\
\hline A102JV-4 & 12.5 & $0.709157(15)$ & 0.112 & 1452 & - & & & & \\
\hline A102JV-5 & 14.5 & $0.709201(7)$ & 0.118 & 1435 & 13.77 & & 7.756 & -0.346 & 0.15 \\
\hline A102JV-6 & 16.4 & 0.709194 (12) & 0.124 & 1319 & 13.65 & \multirow{5}{*}{0.65} & 7.705 & -0.423 & 0.14 \\
\hline A102JV-7 & 19.2 & $0.709169(13)$ & 0.154 & 1474 & 16.80 & & 8.132 & 0.028 & 0.10 \\
\hline A102JV-8 & 22 & $0.709170(5)$ & 0.099 & 1558 & 18.04 & & 8.236 & 0.115 & 0.13 \\
\hline A102JV-9 & 24.8 & $0.709178(6)$ & 0.112 & 1491 & 20.23 & & 8.382 & 0.397 & 0.02 \\
\hline A102JV-10 & 27.6 & $0.709184(6)$ & 0.097 & - & 21.93 & & 8.502 & 0.527 & 0.02 \\
\hline A103JV-1 & 4 & - & - & - & 16.57 & 0.24 & 8.242 & 0.209 & 0.25 \\
\hline A103JV-2 & 8.5 & - & - & - & 16.57 & \multirow{4}{*}{0.51} & 8.225 & 0.186 & 0.25 \\
\hline A103JV-3 & 10.5 & $0.709191(7)$ & - & - & 18.41 & & 8.389 & 0.300 & 0.03 \\
\hline A103JV-4 & 12.5 & $0.709187(5)$ & - & - & 16.04 & & 8.138 & 0.056 & 0.17 \\
\hline A103JV-5 & 14.5 & $0.709195(9)$ & - & - & 16.28 & & 8.145 & 0.043 & 0.11 \\
\hline A103JV-6 & 16.4 & $0.709204(15)$ & - & - & 17.71 & \multirow{5}{*}{0.61} & 8.265 & 0.138 & 0.13 \\
\hline A103JV-7 & 19.2 & - & - & - & 16.57 & & 8.108 & 0.003 & 0.06 \\
\hline A103JV-8 & 22 & $0.709188(6)$ & - & - & 17.45 & & 8.182 & 0.061 & 0.24 \\
\hline A103JV-9 & 24.8 & $0.709182(5)$ & - & - & 19.21 & & 8.305 & 0.319 & 0.07 \\
\hline A103JV-10 & 27.6 & $0.709182(5)$ & - & - & 25.12 & & 8.708 & 0.733 & 0.22 \\
\hline A105JV-1 & 4 & $0.709178(6)$ & 0.227 & 1414 & 14.53 & 0.24 & 7.970 & -0.064 & 0.53 \\
\hline A105JV-2 & 8.5 & $0.709191(7)$ & 0.255 & 1534 & 13.75 & \multirow{4}{*}{0.60} & 7.802 & -0.237 & 0.39 \\
\hline A105JV-3 & 10.5 & $0.709183(6)$ & 0.251 & 1482 & 12.22 & & 7.175 & -0.914 & 0.76 \\
\hline A105JV-4 & 12.5 & $0.709184(5)$ & 0.263 & 1453 & 17.15 & & 8.257 & 0.176 & 0.21 \\
\hline A105JV-5 & 14.5 & $0.709175(7)$ & 0.216 & 1521 & 14.59 & & 7.916 & -0.186 & 0.25 \\
\hline A105JV-6 & 16.4 & $0.709179(6)$ & 0.273 & 2559 & 11.09 & \multirow{5}{*}{0.68} & - & - & 0.30 \\
\hline A105JV-7 & 19.2 & $0.709183(5)$ & 0.296 & 2048 & 12.52 & & 7.272 & -0.833 & 0.33 \\
\hline A105JV-8 & 22 & $0.709163(5)$ & 0.230 & 2204 & 17.41 & & 8.178 & 0.057 & 0.17 \\
\hline A105JV-9 & 24.8 & $0.709186(6)$ & 0.234 & 1850 & 19.43 & & 8.322 & 0.337 & 0.09 \\
\hline A105JV-10 & 27.6 & $0.709177(6)$ & 0.238 & 1795 & 22.11 & & 8.514 & 0.539 & 0.23 \\
\hline
\end{tabular}

${ }^{1}$ Data from Beirne (2011). ${ }^{2} \mathrm{pH}_{\text {shell }}$ was calculated with Eq. (4), in situ temperature and salinity data was used to determine $p K_{\mathrm{b}}$ and $\alpha=1.0272$ was used. ${ }^{3} \Delta \mathrm{pH}$ $\left(\mathrm{pH}_{\text {shell }}-\mathrm{pH}_{\mathrm{sw}}\right) .{ }^{4}$ Propagation error determined from within run standard deviation of shell $\delta^{11} \mathrm{~B}$ (duplication or triplication of the same sample solution).

\section{Discussion}

\subsection{Radiogenic Sr isotope incorporation into A. islandica}

In this study, we measured the radiogenic Sr isotope ratios in seawater to estimate the source water contributions to the culture site, which is situated within the Damariscotta River estuary. The ${ }^{87} \mathrm{Sr} /{ }^{86} \mathrm{Sr}$ ratios in cultured seawater showed identical values to the open surface seawater ratio. Bedrock types in the Gulf of Maine coastal region are dominated by late
Proterozoic and lower Paleozoic sedimentary rocks (Osberg et al., 1985), which would provide a terrestrial source with high ${ }^{87} \mathrm{Sr} /{ }^{86} \mathrm{Sr}$ values. Considering rock type, age and freshwater flux, a recent model of ${ }^{87} \mathrm{Sr} /{ }^{86} \mathrm{Sr}$ for flux-weighted catchment water suggests the ${ }^{87} \mathrm{Sr} /{ }^{86} \mathrm{Sr}$ value to be in a range of 0.7099-0.7145 (Bataille and Bowen, 2012). If river fluxes influence the $\mathrm{Sr}$ isotopic composition of coastal seawater, the value should be enriched in ${ }^{87} \mathrm{Sr}$, driving the ${ }^{87} \mathrm{Sr} /{ }^{86} \mathrm{Sr}$ higher than the current seawater ratio. Therefore, the $\mathrm{Sr}$ isotopic results suggest a negligible amount of terrestrial input into the culture site at the Darling Marine Center. 
The mean ${ }^{87} \mathrm{Sr} /{ }^{86} \mathrm{Sr}$ ratio in the shell is consistent with the isotopic composition in the culture seawater, but with a relatively larger variation between individual shell samples. Therefore, incorporation of radiogenic $\mathrm{Sr}$ ratios into the shells occurs without measurable fractionation and reflects the isotopic composition of ambient seawater. Although the shell ${ }^{87} \mathrm{Sr} /{ }^{86} \mathrm{Sr}$ values have a larger standard deviation compared to the seawater values, they are within the range of the long-term precision of Triton plus at the Department of Earth and Environmental Sciences, University of Michigan (see Sect. 2.2.1). The high content of calcium in carbonate samples, which cannot be fully separated using Sr-specific ion exchange column chemistry, may contribute to the larger variation of shell ${ }^{87} \mathrm{Sr} /{ }^{86} \mathrm{Sr}$ compared to seawater.

\subsection{Stable $\mathrm{Sr}$ isotope incorporation into $A$. islandica, and $\mathrm{Sr}$ concentrations}

In this study we observed no statistically significant correlation of $\delta^{88 / 86} \mathrm{Sr}$ or $\mathrm{Sr}$ concentrations with respect to seawater temperature. The stable $\mathrm{Sr}$ isotopic composition of some biogenic carbonates has been suggested to reflect ambient seawater temperature due to mass-dependent kinetic fractionation, in which the relative mass difference of the isotopes involved accounts for the inverse correlation to the ion mass in a kinetic fractionation process (Fietzke and Eisenhauer, 2006; Rüggeberg et al., 2008). However, more recent work has shown no relationship between seawater temperature and $\delta^{88 / 86} \mathrm{Sr}$ values from various biogenic archives (Böhm et al., 2012; Raddatz et al., 2013; Stevenson et al., 2014; Vollstaedt et al., 2014). Our results support the argument that a simple temperature-dependent kinetic effect is not the primary control on $\delta^{88 / 86} \mathrm{Sr}$ in the aragonite shell of $A$. islandica. The temperature range in the experiment is over $15^{\circ} \mathrm{C}\left(2.4-17.6^{\circ} \mathrm{C}\right)$ and growth rate more than doubled (0.24-0.68 $\mathrm{mm} \mathrm{week}^{-1}$ ) during the experiment, which could result in over $1.5 \%$ change in $8^{88 / 86} \mathrm{Sr}$ if $A$. islandica incorporated ${ }^{88} \mathrm{Sr} /{ }^{86} \mathrm{Sr}$ similarly, as noted by the Stevenson et al. (2014) study on coccolithophores. The lack of a consistent relationship between $\delta^{88 / 86} \mathrm{Sr}$ and temperature or shell growth rates during the experiment indicates that $\delta^{88 / 86} \mathrm{Sr}$ is not controlled by these factors. Thus, it is likely that $\delta^{88 / 86} \mathrm{Sr}$ records derived from $A$. islandica shells reflect ambient seawater conditions and could be a potential archive for studying the global $\mathrm{Sr}$ cycle in the context of chemical weathering (Krabbenhöft et al., 2010; Raddatz et al., 2013; Vollstaedt et al., 2014). More work is needed to fully evaluate this potential proxy.

Our deconvolved shell Sr concentrations show no resolvable relationship with the seawater temperature, despite a possible physiological control on Sr uptake into bivalve shell material. In general, co-precipitation of $\mathrm{Sr}$ to $\mathrm{Ca}$ in aragonite decreases with temperature increases due to a declining distribution coefficient, which has been both measured and derived theoretically (Dietzel et al., 2004). The negative correlation between skeletal $\mathrm{Sr} / \mathrm{Ca}$ ratios observed in some massive corals with ambient seawater temperature has been widely established and applied to reconstruct paleo-seawater temperature (Beck et al., 1992; Corrège, 2006; de Villiers, 1999; McCulloch et al., 1994, 1996; Shen et al., 1996; Weber, 1973; Yan et al., 2013; Yu et al., 2005). However, these relationships may be biased by the influence from symbionts causing an apparent vital effect (Böhm et al., 2012; Cohen et al., 2002, 2006; Stevenson et al., 2014) or by ontogenetic age, grow rates, metabolic activity related to temperature and/or salinity (Purton et al., 1999). Schöne et al. (2011b) observed a strong physiological regulation to $\mathrm{Sr} / \mathrm{Ca}$ and $\mathrm{Mg} / \mathrm{Ca}$ on ontogenetically old adult $A$. islandica records. The metal to calcium ratio $(\mathrm{Me} / \mathrm{Ca})$ increased with shell age when the annual increment widths were below 30-200 $\mu \mathrm{m}$. However, Schöne et al. (2013) concluded that the faster-growing juvenile portion of the shells showed a weak relationship between $\mathrm{Me} / \mathrm{Ca}$ and ambient temperature and results from different specimens were variable. Schöne et al. (2013) proposed that pronounced vital effects may control the trace metal uptake in juvenile shells. Our results are also consistent with the study of Schöne et al. (2011b), where the juvenile portion of the two A. islandica shells with annual growth increments larger than $750 \mu \mathrm{m}$ showed no obvious relationship between $\mathrm{Me} / \mathrm{Ca}$ ratios and growth rates.

\subsection{Controls on $\delta^{11} \mathrm{~B}$ in $A$. islandica and an evaluation of the proxy archive as a seawater $\mathrm{pH}$ indicator}

The range in measured shell $\delta^{11} \mathrm{~B}$ values lies between the prediction lines (Fig. 6b), which suggest that the shell boron content generally reflects the ambient seawater conditions. However, our data do not consistently follow either prediction line. Previous studies on foraminifera have shown offsets between different genera and the empirical $\delta^{11} \mathrm{~B}-\mathrm{pH}$ relationship of $\alpha=1.0194$ (Hönisch and Hemming, 2004). The inconsistency between shell $\delta^{11} \mathrm{~B}$ and either prediction is therefore strong evidence that a species-specific fractionation factor is required for bivalves.

The offsets between our shell data with the predicted trends (Fig. 6b) are likely from vital effects during biomineralization. Previous studies suggested a range of fractionation factors might be applied, and an additional constant offset might better describe the empirical $\delta^{11} \mathrm{~B}-\mathrm{pH}$ relationship (Anagnostou et al., 2012; Hönisch et al., 2004; Rae et al., 2011). Therefore, a species-specific offset may account for the smaller variations before week 19, where many of the results are below the prediction lines and have a negative $\Delta \mathrm{pH}$ value. In this study, because the temperature and salinity were highly variable and $\mathrm{pH}$ changes were relatively small, we cannot determine a precise $\delta^{11} \mathrm{~B}-\mathrm{pH}$ shell transfer function for $A$. islandica. However, the total variation throughout the experiment is about $10 \%$, and has an obvious trend after week 19, suggesting non-pH-related controls on boron incorporation in the shell. 
Rollion-Bard and Erez (2010) and Trotter et al. (2011) evaluated vital effects in corals and foraminifera, and the potential use of the $\delta^{11} \mathrm{~B}-\mathrm{pH}$ relationship in such biogenic carbonates. They observed a $\mathrm{pH}$ offset between calcifying fluid and ambient seawater, and this $\mathrm{pH}$ discrepancy $(\Delta \mathrm{pH})$ increases with decreasing ambient seawater $\mathrm{pH}\left(\mathrm{pH}_{\mathrm{sw}}\right)$. As the environment becomes more acidic, marine calcifiers likely adjust their internal microenvironment during calcification, resulting in larger $\Delta \mathrm{pH}$ values than expected. Under careful culture conditions, species-specific $\Delta \mathrm{pH}-\mathrm{pH}_{\mathrm{sw}}$ relationships can be developed and, after calibration, the corresponding ambient seawater $\mathrm{pH}$ can be determined.

It has been argued that bivalves have the ability to regulate their inner shell fluid chemistry, more specifically the extrapallial fluid (EPF), to achieve a carbonate saturation state in order to facilitate biomineralization (Crenshaw, 1980). Stemmer (2013) observed pH gradients between the inner shell surface and the outer mantle epithelium (OME) of A. islandica via an in situ $\mathrm{pH}$ microscopy method. During a short-term monitoring, Stemmer (2013) also observed the measured $\mathrm{pH}$ rose rapidly as the probe approached the OME. They concluded this elevation was due to active proton uptake by the epithelium. This result suggests a pH selfregulation occurs for $A$. islandica shell precipitation, and the shell will record the regulated calcification $\mathrm{pH}$ in the carbonate shell.

The calculated $\Delta \mathrm{pH}$ shows a statistically significant negative relationship to $\mathrm{pH}_{\mathrm{sw}}\left(R^{2}=0.35 ; p\right.$ value $\left.\leq 0.001\right)$ (Fig. 7). The inverse correlation supports the argument that A. islandica regulate their EPF $\mathrm{pH}$ for calcification. However, only $35 \%$ of the variability can be explained by $\Delta \mathrm{pH}$, which indicates that the $\mathrm{pH}$ regulation in the EPF is likely not the prevailing factor. Instead, we found a rapid increase of the shell $\delta^{11} \mathrm{~B}$ when temperature increased over $13^{\circ} \mathrm{C}$ (Fig. 8a). This rapid change in boron isotopic composition can be explained with respect to two factors: (1) a growthrate-controlled vital effect, or (2) a temperature-controlled vital effect.

Herfort et al. (2008) suggested that carbonate species are the limiting factor in coral calcium precipitation rather than calcium: when ambient seawater temperature increases $\left[\mathrm{CO}_{2}\right]_{\text {aq }}$ decreases and leads to a rising $\left[\mathrm{CO}_{3}^{-2}\right]$ and calcification rate. The rapid growth rate change is likely related to spring bloom. Our data show no statistically significant correlation between shell $\delta^{11} \mathrm{~B}$ and shell growth rates, indicating shell growth is not causing the boron isotope deviation in the culture experiment (Fig. 8b). Therefore, the associated change in shell $\delta^{11} \mathrm{~B}$ with elevated seawater temperatures and the lack of correlation with shell growth rates to the shell $\delta^{11} \mathrm{~B}$ deviation after week 19 cannot be explained by a temperature-controlled growth/precipitation effect.

Alternatively, a proton removal mechanism via $\mathrm{Ca}^{+2}$ ATPase from the site of calcification has been proposed. This mechanism raises the $\mathrm{pH}$ of the calcification solution (Dissard et al., 2012; Rollion-Bard et al., 2011b). In this scenario,
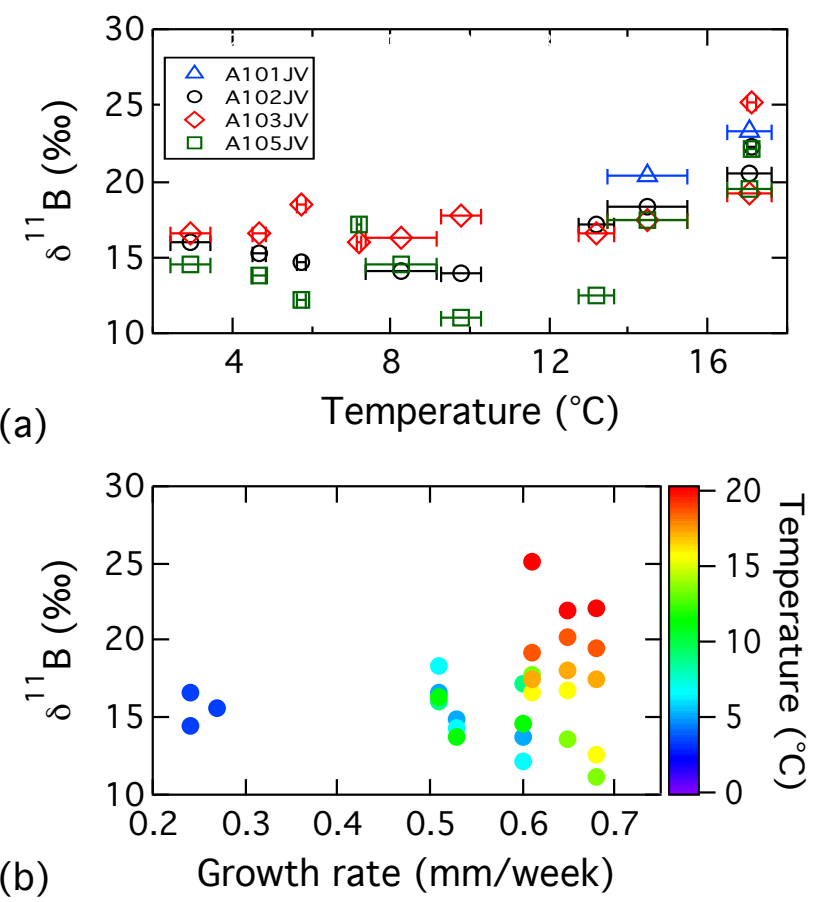

Figure 8. The comparisons between the shell $\delta^{11} \mathrm{~B}$ and (a) the corresponding culture water temperature and (b) the growth rates for individual shells. Colors shown in (b) represent the temperature corresponding to each data point, with low temperatures in blue to high temperatures in red.

the activity of the enzyme is enhanced when a certain temperature has been reached, accelerating the proton removal process and resulting in a higher boron isotopic composition in the calcification solution with respect to the elevated $\mathrm{pH}$. We suggest that there may be a temperature threshold of the boron incorporation into the shell aragonite of $A$. islandica. This proposed threshold may be related to the upper-end thermal tolerance of $A$. islandica, which is generally a cold water species. For example, below $13{ }^{\circ} \mathrm{C}$, the $\delta^{11} \mathrm{~B}$ values closely matched the predicted model of Klochko et al. (2006), supporting the assumption that borate is the dominant species incorporated into the shell. Thus, we suggest that shell-derived $\delta^{11} \mathrm{~B}$ in A. islandica reflect the ambient seawater $\mathrm{pH}$ at temperatures below $\sim 13^{\circ} \mathrm{C}$. At temperatures above $13^{\circ} \mathrm{C}$ the utility of shell $\delta^{11} \mathrm{~B}$ values as a $\mathrm{pH}$ indicator is questionable and likely unreliable. We suggest that the thermal tolerance of A. islandica was exceeded in the summer growing season in the culture conditions, causing biological stress on the animals.

\section{Conclusions}

Here we examined the radiogenic and stable isotopic composition of strontium and the stable isotopic composition of boron recorded in the aragonitic shell material of cultured 
A. islandica with in situ seawater temperature, salinity and $\mathrm{pH}$ measurements. Both seawater and shell ${ }^{87} \mathrm{Sr} /{ }^{86} \mathrm{Sr}$ show identical values to the mean global seawater composition, suggesting there is trivial influence from local continental runoff. Shell $\delta^{88 / 86} \mathrm{Sr}$ and $\mathrm{Sr}$ concentration values during the culture season were not influenced by seawater temperature or calcification rates. These results suggest that wellpreserved subfossil specimens may be used to determine the past isotopic composition $\left({ }^{87} \mathrm{Sr} /{ }^{86} \mathrm{Sr}\right.$ and $\left.\delta^{88 / 86} \mathrm{Sr}\right)$ of seawater.

The boron isotope results from the cultured aragonite $A$. islandica shells are generally within the range of two prediction lines utilizing previously published fractionation factors. Although, to first order, these results indicate that the shell $\delta^{11} \mathrm{~B}$ values reflect ambient conditions, substantial variability unrelated to $\mathrm{pH}$ changes was noted. The 5-8\%o increase in shell $\delta^{11} \mathrm{~B}$ values is larger than theoretical predictions based on in situ seawater temperature, salinity, $\mathrm{pH}$ and conventional boron fractionation factors for corals and foraminifera. A species-specific $\delta^{11} \mathrm{~B}-\mathrm{pH}$ transfer function is recommended for bivalve species because of their inherent ability to selfregulate calcifying fluids. The statistically significant relationship $\left(R^{2}=0.35\right)$ between $\Delta \mathrm{pH}$ and $\mathrm{pH}_{\mathrm{sw}}$ indicates that A. islandica does regulate the $\mathrm{EPF} \mathrm{pH}$ during calcification, but self-regulation is not the primary control on shell $\delta^{11} \mathrm{~B}$. The largest increase in shell $\delta^{11} \mathrm{~B}$ values was observed after crossing an apparent temperature threshold at $13{ }^{\circ} \mathrm{C}$, suggesting a possible influence from biological processes. To better evaluate the potential of $\delta^{11} \mathrm{~B}$ as a seawater $\mathrm{pH}$ indicator in A. islandica shell material, a $\mathrm{pH}$-controlled culture experiment with a large $\mathrm{pH}$ range (0.4-0.6 units) and with limited seawater temperature and salinity variation is needed.

Acknowledgements. We thank R. I. Gabitov and one anonymous referee for their constructive comments, which substantially improved the manuscript. This project was funded by grants from the Rackham Graduate School and the Department of Earth and Environmental Sciences at the University of Michigan to Y.-W. Liu and from the Packard Foundation to S. M. Aciego. We thank Tsuyoshi Watanabe, Hokkaido University, Japan for providing an aliquot of the international coral standard (JCp-1).

Edited by: D. Gillikin

\section{References}

Aarons, S. M., Aciego, S. M., and Gleason, J. D.: Variable HfS$\mathrm{rNd}$ radiogenic isotopic compositions in a Saharan dust storm over the Atlantic: Implications for dust flux to oceans, ice sheets and the terrestrial biosphere, Chem. Geol., 349-350, 18-26, doi:10.1016/j.chemgeo.2013.04.010, 2013.

Anagnostou, E., Huang, K. F., You, C. F., Sikes, E. L., and Sherrel, R. M.: Evaluation of boron isotope ratio as a $\mathrm{pH}$ proxy in the deep sea coral Desmophyllum dianthus: Evidence of physiological $\mathrm{pH}$ adjustment, Earth Planet. Sc. Lett., 349, 251-260, 2012.
Barker, S., Greaves, M., and Elderfield, H.: A study of cleaning procedures used for foraminiferal $\mathrm{Mg} / \mathrm{Ca}$ paleothermometry, Geochem. Geophy. Geosy., 4, 8407, doi:10.1029/2003gc000559, 2003.

Bataille, C. P. and Bowen, G. J.: Mapping ${ }^{87} \mathrm{Sr} /{ }^{86} \mathrm{Sr}$ variations in bedrock and water for large scale provenance studies, Chem. Geol., 304-305, 39-52, doi:10.1016/j.chemgeo.2012.01.028, 2012.

Beck, J. W., Edwards, R. L., Ito, E., Taylor, F. W., Recy, J., Rougerie, F., Joannot, P., and Henin, C.: Sea-Surface Temperature from Coral Skeletal Strontium/Calcium Ratios, Science, 257, 644-647, doi:10.1126/science.257.5070.644, 1992.

Beirne, E. C.: Pursuing a proxy for carbon cycling in the temperate North Atlantic: Investigation of the utility of Arctica islandica shell carbonate to millennial-scale dissolved inorganic carbon reconstructions, MS thesis, Paper 10124, Geological and Atmospheric Sciences, Graduate Theses and Dissertations, Iowa State University, Ames, 193 pp., 2011.

Beirne, E. C., Wanamaker Jr., A. D., and Feindel, S. C.: Experimental validation of environmental controls on the $\delta^{13} \mathrm{C}$ of Arctica islandica (ocean quahog) shell carbonate, Geochim. Cosmochim. Acta, 84, 395-409, doi:10.1016/j.gca.2012.01.021, 2012.

Berglund, M. and Wieser, M. E.: Isotopic compositions of the elements 2009 (IUPAC Technical Report), Pure Appl. Chem., 83, 397-410, 2011.

Boelrijk, N. A. I. M.: A general formula for "double" isotope dilution analysis, Chem. Geol., 3, 323-325, 1968.

Böhm, F., Eisenhauer, A., Tang, J., Dietzel, M., Krabbenhöft, A., Kisakürek, B., and Horn, C.: Strontium isotope fractionation of planktic foraminifera and inorganic calcite, Geochim. Cosmochim. Acta, 93, 300-314, doi:10.1016/j.gca.2012.04.038, 2012.

Broecker, W. S.: Radioisotopes and large-scale oceanic mixing, Interscience, New York, 88-108, 1963.

Butler, P. G., Scourse, J. D., Richardson, C. A., Wanamaker Jr., A. D., Bryant, C. L., and Bennell, J. D.: Continuous marine radiocarbon reservoir calibration and the ${ }^{13} \mathrm{C}$ Suess effect in the Irish Sea: Results from the first multi-centennial shell-based marine master chronology, Earth Planet. Sc. Lett., 279, 230-241, 2009.

Butler, P. G., Richardson, C. A., Scourse, J. D., Wanamaker Jr., A. D., Shammon, T. M., and Bennell, J. D.: Marine climate in the Irish Sea: analysis of a 489-year marine master chronology derived from growth increments in the shell of the clam Arctica islandica, Quaternary Sci. Rev., 29, 1614-1632, 2010.

Butler, P. G., Wanamaker Jr., A. D., Scourse, J. D., Richardson, C. A., and Reynolds, D. J.: Long-term stability of $\delta^{13} \mathrm{C}$ with respect to biological age in the aragonite shell of mature specimens of the bivalve mollusk Arctica islandica, Palaeogeogr. Palaeocl., 302, 21-30, 2011.

Butler, P. G., Wanamaker Jr., A. D., Scourse, J. D., Richardson, C. A., and Reynolds, D. J.: Variability of marine climate on the North Icelandic Shelf in a 1357-year proxy archive based on growth increments in the bivalve Arctica islandica, Palaeogeogr., Palaeocl., 373, 141-151, doi:10.1016/j.palaeo.2012.01.016, 2013.

Byrne, R. H., Mecking, S., Feely, R. A., and Liu, X.: Direct observations of basin-wide acidification of the North Pacific Ocean, Geophys. Res. Lett., 37, L02601, doi:10.1029/2009GL040999, 2010. 
Chung, C.-H., You, C.-F., and Chu, H.-Y.: Weathering sources in the Gaoping (Kaoping) river catchments, southwestern Taiwan: Insights from major elements, Sr isotopes, and rare earth elements, J. Mar. Syst., 76, 433-443, 2009.

Cohen, A. L., Owens, K. E., Layne, G. D., and Shimizu, N.: The Effect of Algal Symbionts on the Accuracy of Sr/Ca Paleotemperatures from Coral, Science, 296, 331-333, doi:10.1126/science.1069330, 2002.

Cohen, A. L., Gaetani, G. A., Lundälv, T., Corliss, B. H., and George, R. Y.: Compositional variability in a cold-water scleractinian, Lophelia pertusa: New insights into "vital effects", Geochem. Geophy. Geosy., 7, Q12004, doi:10.1029/2006GC001354, 2006.

Corrège, T.: Sea surface temperature and salinity reconstruction from coral geochemical tracers, Palaeogeogr. Palaeocl., 232, 408-428, doi:10.1016/j.palaeo.2005.10.014, 2006.

Crenshaw, M. A.: Mechanisms of shell formation and dissolution, in: Skeletal Growth of Aquatic Organisms, edited by: Rhoads, D. C. and Lutz, R. A., Plenum, New York, 115-132, 1980.

de Villiers, S.: Seawater strontium and $\mathrm{Sr} / \mathrm{Ca}$ variability in the Atlantic and Pacific oceans, Earth Planet. Sc. Lett., 171, 623-634, doi:10.1016/S0012-821X(99)00174-0, 1999.

Dietzel, M., Gussone, N., and Eisenhauer, A.: Co-precipitation of $\mathrm{Sr}^{2+}$ and $\mathrm{Ba}^{2+}$ with aragonite by membrane diffusion of $\mathrm{CO}_{2}$ between 10 and $50{ }^{\circ} \mathrm{C}$, Chem. Geol., 203, 139-151, doi10.1016/j.chemgeo.2003.09.008, 2004.

Dissard, D., Douville, E., Reynaud, S., Juillet-Leclerc, A., Montagna, P., Louvat, P., and McCulloch, M.: Light and temperature effects on $\delta^{11} \mathrm{~B}$ and $\mathrm{B} / \mathrm{Ca}$ ratios of the zooxanthellate coral Acropora $s p$.: results from culturing experiments, Biogeosciences, 9 , 4589-4605, doi:10.5194/bg-9-4589-2012, 2012.

Dodson, M. H.: A theoretical study of the use of internal standards for precise isotopic analysis by the surface ionization technique: Part I - General first-order algebraic solutions, J. Phys. E, 40, 289-295, 1963.

DOE: Handbook of methods for the analysis of the various parameters of the carbon dioxide system in sea water, Version 2, ORNL/CDIAC-74, Carbon Dioxide Information and Analysis Center, Oak Ridge, 1994.

D’Olivo, J. P., McCulloch, M. T., Eggins, S. M., and Trotter, J.: Coral records of reef-water $\mathrm{pH}$ across the central Great Barrier Reef, Australia: assessing the influence of river runoff on inshore reefs, Biogeosciences, 12, 1223-1236, doi:10.5194/bg-12-12232015, 2015.

Doney, S. C., Fabry, V. J., Feely, R. A., and Kleypas, J. A.: Ocean Acidification: The Other $\mathrm{CO}_{2}$ Problem, Annu. Rev. Mar. Sci., 1, 169-192, doi:10.1146/annurev.marine.010908.163834, 2009.

Dore, J. E., Lukas, R., Sadler, D. W., Church, M. J., and Karl, D. M.: Physical and Biogeochemical Modulation of Ocean Acidification in the Central North Pacific, P. Natl. Acad. Sci. USA, 106, 12235-12240, doi:10.1073/pnas.0906044106, 2009.

Feely, R. A., Sabine, C. L., Lee, K., Berelson, W., Kleypas, J., Fabry, V. J., and Millero, F. J.: Impact of Anthropogenic $\mathrm{CO}_{2}$ on the $\mathrm{CaCO}_{3}$ System in the Oceans, Science, 305, 362-366, doi:10.1126/science.1097329, 2004.

Fietzke, J. and Eisenhauer, A.: Determination of temperaturedependent stable strontium isotope $\left({ }^{88} \mathrm{Sr} /{ }^{86} \mathrm{Sr}\right)$ fractionation via bracketing standard MC-ICP-MS, Geochem. Geophy. Geosy., 7, Q08009, doi:10.1029/2006GC001243, 2006.
Foster, G. L.: Seawater $\mathrm{pH}, \mathrm{pCO}_{2}$ and $\left[\mathrm{CO}_{3}^{2-}\right]$ variations in the Caribbean Sea over the last $130 \mathrm{kyr}$ : A boron isotope and $\mathrm{B} / \mathrm{Ca}$ study of planktic foraminifera, Earth Planet. Sc. Lett., 271, 254266, 2008.

Foster, G. L., Pogge von Strandmann, P. A. E., and Rae, J. W. B.: Boron and magnesium isotopic composition of seawater, Geochem. Geophy. Geosy., 11, Q08015, doi:10.1029/2010GC003201, 2010.

Galer, S. J. G.: Optimal double and triple spiking for high precision lead isotopic measurement, Chem. Geol., 157, 255-274, 1999.

Goldberg, E. D.: The oceans as a chemical system, Interscience, New York, 3-25, 1963.

Heinemann, A., Fietzke, J., Melzner, F., Böhm, F., Thomsen, J., Garbe-Schönberg, D., and Eisenhauer, A.: Conditions of Mytilus edulis extracellular body fluids and shell composition in a pH-treatment experiment: Acid-base status, trace elements and $\delta^{11} \mathrm{~B}$, Geochem. Geophy. Geosy., 13, Q01005, doi:10.1029/2011GC003790, 2012.

Henehan, M. J., Rae, J. W. B., Foster, G. L., Erez, J., Prentice, K. C., Kucera, M., Bostock, H. C., Martínez-Botí, M. A., Milton, J. A., Wilson, P. A., Marshall, B. J., and Elliott, T.: Calibration of the boron isotope proxy in the planktonic foraminifera Globigerinoides ruber for use in palaeo- $\mathrm{CO}_{2}$ reconstruction, Earth Planet. Sc. Lett., 364, 111-122, doi:10.1016/j.epsl.2012.12.029, 2013.

Herfort, L., Thake, B., and Taubner, I.: Bicarbonate stimulation of calcification and photosynthesis in two hermatypic corals, J. Phycol., 44, 91-98, doi:10.1111/j.1529-8817.2007.00445.x, 2008.

Hofmann, G. E., Barry, J. P., Edmunds, P. J., Gates, R. D., Hutchins, D. A., Klinger, T., and Sewell, M. A.: The Effect of Ocean Acidification on Calcifying Organisms in Marine Ecosystems: An Organism-to-Ecosystem Perspective, Annu. Rev. Ecol. Evol. Syst., 41, 127-147, doi:10.1146/annurev.ecolsys.110308.120227, 2010.

Hönisch, B. and Hemming, N. G.: Ground-truthing the boron isotope-paleo-pH proxy in planktonic foraminifera shells: Partial dissolution and shell size effects, Paleoceanography, 19, PA4010, doi:10.1029/2004PA001026, 2004.

Hönisch, B., Hemming, N. G., Grottoli, A. G., Amat, A., Hanson, G. N., and Bijma, J.: Assessing scleractinian corals as recorders for paleo-pH: Empirical calibration and vital effects, Geochim. Cosmochim. Acta, 68, 3675-3685, doi:10.1016/j.gca.2004.03.002, 2004.

Hönisch, B., Ridgwell, A., Schmidt, D. N., Thomas, E., Gibbs, S. J., Sluijs, A., Zeebe, R., Kump, L., Martindale, R. C., and Greene, S. E.: The geological record of ocean acidification, Science, 335, 1058-1063, 2012.

Huang, K.-F. and You, C.-F.: Tracing freshwater plume migration in the estuary after a typhoon event using $\mathrm{Sr}$ isotopic ratios, Geophys. Res. Lett., 34, L02403, doi:10.1029/2006GL028253, 2007.

Huang, K.-F., You, C.-F., Chung, C.-H., and Lin, I.-T.: Nonhomogeneous seawater $\mathrm{Sr}$ isotopic composition in the coastal oceans: A novel tool for tracing water masses and submarine groundwater discharge, Geochem. Geophy. Geosy., 12, Q05002, doi:10.1029/2010GC003372, 2011.

IPCC: Climate Change 2013: The Physical Science Basis, Working Group I Contribution to the IPCC 5th Assessment Report - Changes to the Underlying Scientific/Technical Assessment, Cambridge, UK and New York, NY, USA, 2013. 
Jahn, B.-M., Gallet, S., and Han, J.: Geochemistry of the Xining, Xifeng and Jixian sections, Loess Plateau of China: eolian dust provenance and paleosol evolution during the last $140 \mathrm{ka}$, Chem. Geol., 178, 71-94, 2001.

Jones, D. S.: Annual Cycle of Shell Growth Increment Formation in Two Continental Shelf Bivalves and its Paleoecologic Significance, Paleobiology, 6, 331-340, 1980.

Kakihana, H., Kotaka, M., Satoh, S., Nomura, M., and Okamoto, M.: Fundamental studies on the ion-exchange separation of boron isotopes, Bull. Chem. Soc. Jpn., 50, 158-163, 1977.

Klochko, K., Kaufman, A. J., Yao, W., Byrne, R. H., and Tossell, J. A.: Experimental measurement of boron isotope fractionation in seawater, Earth Planet. Sc. Lett., 248, 276-285, doi:10.1016/j.epsl.2006.05.034, 2006.

Klochko, K., Cody, G. D., Tossell, J. A., Dera, P., and Kaufman, A. J.: Re-evaluating boron speciation in biogenic calcite and aragonite using ${ }^{11} \mathrm{~B}$ MAS NMR, Geochim. Cosmochim. Acta, 73, 1890-1900, 2009.

Krabbenhöft, A., Fietzke, J., Eisenhauer, A., Liebetrau, V., Bohm, F., and Vollstaedt, H.: Determination of radiogenic and stable strontium isotope ratios $\left({ }^{87} \mathrm{Sr} /{ }^{86} \mathrm{Sr} ; \delta^{88 / 86} \mathrm{Sr}\right)$ by thermal ionization mass spectrometry applying an ${ }^{87} \mathrm{Sr} /{ }^{84} \mathrm{Sr}$ double spike, J. Anal. At. Spectrom., 24, 1267-1271, 2009.

Krabbenhöft, A., Eisenhauer, A., Böhm, F., Vollstaedt, H., Fietzke, J., Liebetrau, V., Augustin, N., Peucker-Ehrenbrink, B., Müller, M. N., Horn, C., Hansen, B. T., Nolte, N., and Wallmann, K.: Constraining the marine strontium budget with natural strontium isotope fractionations $\left({ }^{87} \mathrm{Sr} /{ }^{86} \mathrm{Sr} *, \delta^{88 / 86} \mathrm{Sr}\right)$ of carbonates, hydrothermal solutions and river waters, Geochim. Cosmochim. Acta, 74, 4097-4109, 2010.

Krief, S., Hendy, E. J., Fine, M., Yam, R., Meibom, A., Foster, G. L., and Shemesh, A.: Physiological and isotopic responses of scleractinian corals to ocean acidification, Geochim. Cosmochim. Acta, 74, 4988-5001, doi:10.1016/j.gca.2010.05.023, 2010.

Kroeker, K. J., Kordas, R. L., Crim, R. N., and Singh, G. G.: Meta-analysis reveals negative yet variable effects of ocean acidification on marine organisms, Ecol. Lett., 13, 1419-1434, doi:10.1111/j.1461-0248.2010.01518.x, 2010.

Krogh, T. E.: Strontium isotope variation and whole-rock rubidiumstrontium studies in the Grenville province of Ontario, Ph.D. thesis, Department of Geology and Geophysics, Massachusetts Institute of Technology, Cambridge, 1964.

Lemarchand, D., Gaillardet, J., Lewin, E., and Allegre, C. J.: The influence of rivers on marine boron isotopes and implications for reconstructing past ocean $\mathrm{pH}$, Nature, 408, 951-954, 2000.

Liu, Y.-W.: Natural variation of Sr isotopes in coral Porites collected from Nanwan Bay, southern tip of Taiwan, MS thesis, Department of Geosciences, National Taiwan University, Taipei, 1-78, 2010.

Liu, Y.-W., Aciego, S. M., Wanamaker, A. D., and Sell, B. K.: A high-throughput system for boron microsublimation and isotope analysis by total evaporation thermal ionization mass spectrometry, Rapid Commun. Mass Spectrom., 27, 1705-1714, doi:10.1002/rcm.6619, 2013.

Long, L. E.: Isotope dilution analysis of common and radiogenic strontium using ${ }^{84}$ Sr-enriched spike, Earth Planet. Sc. Lett., 1, 289-292, 1966.
Marchitto, T. M., Jones, G. A., Goodfriend, G. A., and Weidman, C. R.: Precise Temporal Correlation of Holocene Mollusk Shells Using Sclerochronology, Quatern. Res., 53, 236-246, 2000.

Maurer, A.-F., Galer, S. J. G., Knipper, C., Beierlein, L., Nunn, E. V., Peters, D., Tütken, T., Alt, K. W., and Schöne, B. R.: Bioavailable ${ }^{87} \mathrm{Sr} /{ }^{86} \mathrm{Sr}$ in different environmental samples - Effects of anthropogenic contamination and implications for isoscapes in past migration studies, Sci. Total Environ., 433, 216-229, doi:10.1016/j.scitotenv.2012.06.046, 2012.

McCulloch, M. T., Gagan, M. K., Mortimer, G. E., Chivas, A. R., and Isdale, P. J.: A high-resolution $\mathrm{Sr} / \mathrm{Ca}$ and $\delta^{18} \mathrm{O}$ coral record from the Great Barrier Reef, Australia, and the 1982-1983 El Niño, Geochim. Cosmochim. Acta, 58, 2747-2754, 1994.

McCulloch, M. T., Mortimer, G., Esat, T., Xianhua, L., Pillans, B., and Chappell, J.: High resolution windows into early Holocene climate: Sr/Ca coral records from the Huon Peninsula, Earth Planet. Sc. Lett., 138, 169-178, 1996.

Merrill, A. and Ropes, J. W.: The general distribution of the surf clam and ocean quahog Spisula-solidissima Arctica-islandica, J. Shellfish Res., 59, 40-45, 1968.

Ni, Y., Foster, G. L., Bailey, T., Elliott, T., Schmidt, D. N., Pearson, P., Haley, B., and Coath, C.: A core top assessment of proxies for the ocean carbonate system in surface-dwelling foraminifers, $\mathrm{Pa}$ leoceanography, 22, PA3212, doi:10.1029/2006PA001337, 2007.

Nicol, D.: Recent species of the veneroid pelecypod Arctica, J. Washington Acad. Sci., 41, 102-106, 1951.

Nir, O., Vengosh, A., Harkness, J. S., Dwyer, G. S., and Lahav, O.: Direct measurement of the boron isotope fractionation factor: Reducing the uncertainty in reconstructing ocean paleo-pH, Earth Planet. Sc. Lett., 414, 1-5, doi:10.1016/j.epsl.2015.01.006, 2015.

Orr, J. C., Fabry, V. J., Aumont, O., Bopp, L., Doney, S. C., Feely, R. A., Gnanadesikan, A., Gruber, N., Ishida, A., Joos, F., Key, R. M., Lindsay, K., Maier-Reimer, E., Matear, R., Monfray, P., Mouchet, A., Najjar, R. G., Plattner, G.-K., Rodgers, K. B., Sabine, C. L., Sarmiento, J. L., Schlitzer, R., Slater, R. D., Totterdell, I. J., Weirig, M.-F., Yamanaka, Y., and Yool, A.: Anthropogenic ocean acidification over the twenty-first century and its impact on calcifying organisms, Nature, 437, 681-686, 2005.

Osberg, P. H., Hussey, A. M., and Boone, G. M.: Bedrock geologic map of Maine, Maine Geological Sruvay, Geologic Map Esries BGMM, color map, scale 1 : 500,000, Maine Geological Sruvay, Augusta, Maine, 1985.

Patchett, P. J.: Sr isotopic fractionation in $\mathrm{Ca}-\mathrm{Al}$ inclusions from the Allende meteorite, Nature, 283, 438-441, 1980a.

Patchett, P. J.: Sr isotopic fractionation in Allende chondrules: A reflection of solar nebular processes, Earth Planet. Sc. Lett., 50, 181-188, 1980b.

Penman, D. E., Hönisch, B., Rasbury, E. T., Hemming, N. G., and Spero, H. J.: Boron, carbon, and oxygen isotopic composition of brachiopod shells: Intra-shell variability, controls, and potential as a paleo-pH recorder, Chem. Geol., 340, 32-39, doi:10.1016/j.chemgeo.2012.11.016, 2012.

Purton, L. M. A., Shields, G. A., Brasier, M. D., and Grime, G. W.: Metabolism controls $\mathrm{Sr} / \mathrm{Ca}$ ratios in fossil aragonitic mollusks, Geology, 27, 1083-1086, doi:10.1130/00917613(1999)027<1083:mcscri>2.3.co;2, 1999.

Raddatz, J., Liebetrau, V., Rüggeberg, A., Hathorne, E., Krabbenhöft, A., Eisenhauer, A., Böhm, F., Vollstaedt, H., Fietzke, J., 
López Correa, M., Freiwald, A., and Dullo, W. C.: Stable Srisotope, $\mathrm{Sr} / \mathrm{Ca}, \mathrm{Mg} / \mathrm{Ca}, \mathrm{Li} / \mathrm{Ca}$ and $\mathrm{Mg} / \mathrm{Li}$ ratios in the scleractinian cold-water coral Lophelia pertusa, Chem. Geol., 352, 143152, doi:10.1016/j.chemgeo.2013.06.013, 2013.

Rae, J. W. B., Foster, G. L., Schmidt, D. N., and Elliott, T.: Boron isotopes and $\mathrm{B} / \mathrm{Ca}$ in benthic foraminifera: Proxies for the deep ocean carbonate system, Earth Planet. Sc. Lett., 302, 403-413, 2011.

Reynaud, S., Hemming, N. G., Juillet-Leclerc, A., and Gattuso, J.P.: Effect of $\mathrm{pCO}_{2}$ and temperature on the boron isotopic composition of the zooxanthellate coral Acropora sp, Coral Reefs, 23, 539-546, doi:10.1007/s00338-004-0399-5, 2004.

Reynaud, S., Rollion-Bard, C., Martin, S., Rolopho-Metalpa, R., and Gattuso, J.-P.: Effect of elevated $p \mathrm{CO}_{2}$ on the boron isotopic composition into the Mediterranean scleractinian coral Cladocora caespitosa, Impacts of Acidification on Biological, Chemical, and Physical Systems in the Mediterranean and Black Seas, ZOOREC:ZOOR14704033379, No. 36 in CIESM Workshop Monographs, Monaco, 2008.

Riebesell, U., Gattuso, J.-P., Thingstad, T., and Middelburg, J.: Preface "Arctic ocean acidification: pelagic ecosystem and biogeochemical responses during a mesocosm study", Biogeosciences, 10, 5619-5626, doi:10.5194/bg-10-5619-2013, 2013.

Rollion-Bard, C. and Erez, J.: Intra-shell boron isotope ratios in the symbiont-bearing benthic foraminiferan Amphistegina lobifera: Implications for $\delta^{11} \mathrm{~B}$ vital effects and paleo-pH reconstructions, Geochim. Cosmochim. Acta, 74, 1530-1536, 2010.

Rollion-Bard, C., Blamart, D., Trebosc, J., Tricot, G., Mussi, A., and Cuif, J.-P.: Boron isotopes as pH proxy: A new look at boron speciation in deep-sea corals using ${ }^{11} \mathrm{~B}$ MAS NMR and EELS, Geochim. Cosmochim. Acta, 75, 1003-1012, 2011a.

Rollion-Bard, C., Chaussidon, M., and France-Lanord, C.: Biological control of internal $\mathrm{pH}$ in scleractinian corals: Implications on paleo-pH and paleo-temperature reconstructions, Comptes Rendus Geoscience, 343, 397-405, 2011 b.

Rüggeberg, A., Fietzke, J., Liebetrau, V., Eisenhauer, A., Dullo, W.-C., and Freiwald, A.: Stable strontium isotopes $\left(\delta^{88 / 86} \mathrm{Sr}\right)$ in cold-water corals - A new proxy for reconstruction of intermediate ocean water temperatures, Earth Planet. Sc. Lett., 269, 570-575, doi:10.1016/j.eps1.2008.03.002, 2008.

Sabine, C. L., Feely, R. A., Gruber, N., Key, R. M., Lee, K., Bullister, J. L., Wanninkhof, R., Wong, C., Wallace, D. W., and Tilbrook, B.: The oceanic sink for anthropogenic $\mathrm{CO}_{2}$, Science, 305, 367-371, 2004.

Sanyal, A., Hemming, N. G., Hanson, G. N., and Broecker, W. S.: Evidence for a higher $\mathrm{pH}$ in the glacial ocean from boron isotopes in foraminifera, Nature, 373, 234-236, 1995.

Schöne, B. R., Oschmann, W., Rössler, J., Castro, A. D. F., Houk, S. D., Kröncke, I., Dreyer, W., Janssen, R., Rumohr, H., and Dunca, E.: North Atlantic Oscillation dynamics recorded in shells of a long-lived bivalve mollusk, Geology, 31, 1037-1040, 2003.

Schöne, B. R., Fiebig, J., Pfeiffer, M., Gleß, R., Hickson, J., Johnson, A. L. A., Dreyer, W., and Oschmann, W.: Climate records from a bivalved Methuselah (Arctica islandica, Mollusca; Iceland), Palaeogeogr. Palaeocl., 228, 130-148, 2005.

Schöne, B. R., Wanamaker Jr., A. D., Fiebig, J., Thébault, J., and Kreutz, K.: Annually resolved $\delta^{13} \mathrm{C}$ shell chronologies of longlived bivalve mollusks (Arctica islandica) reveal oceanic car- bon dynamics in the temperate North Atlantic during recent centuries, Palaeogeogr. Palaeocl., 302, 31-42, 2011 a.

Schöne, B. R., Zhang, Z., Radermacher, P., Thébault, J., Jacob, D. E., Nunn, E. V., and Maurer, A.-F.: $\mathrm{Sr} / \mathrm{Ca}$ and $\mathrm{Mg} / \mathrm{Ca}$ ratios of ontogenetically old, long-lived bivalve shells (Arctica islandica) and their function as paleotemperature proxies, Palaeogeogr. Palaeocl., 302, 52-64, 2011 b.

Schöne, B. R., Radermacher, P., Zhang, Z., and Jacob, D. E.: Crystal fabrics and element impurities $(\mathrm{Sr} / \mathrm{Ca}, \mathrm{Mg} / \mathrm{Ca}$, and $\mathrm{Ba} / \mathrm{Ca})$ in shells of Arctica islandica - Implications for paleoclimate reconstructions, Palaeogeogr. Palaeocl., 373, 50-59, 2013.

Scourse, J. D., Richardson, C., Forsythe, G., Harris, I., Heinemeier, J., Fraser, N., Briffa, K., and Jones, P.: First cross-matched floating chronology from the marine fossil record: data from growth lines of the long-lived bivalve mollusc Arctica islandica, Holocene, 16, 967-974, 2006.

Scourse, J. D., Wanamaker Jr., A. D., Weidman, C. R., Heinemeier, J., Reimer, P. J., Butler, P. G., Witbaard, R., and Richardson, C. A.: The marine radiocarbon bomb pulse across the temperate North Atlantic: a compilation of $\delta^{14} \mathrm{C}$ time histories from Arctica islandica growth increments, Radiocarbon, 54, 165-186, 2012.

Shen, C.-C., Lee, T., Chen, C.-Y., Wang, C.-H., Dai, C.-F., and Li, L.-A.: The calibration of $\mathrm{D}[\mathrm{Sr} / \mathrm{Ca}]$ versus sea surface temperature relationship for Porites corals, Geochim. Cosmochim. Acta, 60, 3849-3858, 1996.

Shinjo, R., Asami, R., Huang, K.-F., You, C.-F., and Iryu, Y.: Ocean acidification trend in the tropical North Pacific since the mid20th century reconstructed from a coral archive, Mar. Geol., 342, 58-64, doi:10.1016/j.margeo.2013.06.002, 2013.

Stemmer, K.: Shell formation and microstucture of the ocean quahog Arctica islandica: Does ocean acidification matter?, $\mathrm{PhD}$ thesis, Staats- und Universitaetsbibliothek Bremen, Bremen, 143 pp., 2013.

Stevenson, E. I., Hermoso, M., Rickaby, R. E. M., Tyler, J. J., Minoletti, F., Parkinson, I. J., Mokadem, F., and Burton, K. W.: Controls on stable strontium isotope fractionation in coccolithophores with implications for the marine Sr cycle, Geochim. Cosmochim. Acta, 128, 225-235, doi:10.1016/j.gca.2013.11.043, 2014.

Trotter, J., Montagna, P., McCulloch, M., Silenzi, S., Reynaud, S., Mortimer, G., Martin, S., Ferrier-Pagès, C., Gattuso, J.-P., and Rodolfo-Metalpa, R.: Quantifying the $\mathrm{pH}$ 'vital effect' in the temperate zooxanthellate coral Cladocora caespitosa: Validation of the boron seawater pH proxy, Earth Planet. Sc. Lett., 303, 163 173, doi:10.1016/j.epsl.2011.01.030, 2011.

Vázquez-Rodríguez, M., Pérez, F. F., Velo, A., Ríos, A. F., and Mercier, H.: Observed acidification trends in North Atlantic water masses, Biogeosciences, 9, 5217-5230, doi:10.5194/bg-95217-2012, 2012.

Vollstaedt, H., Eisenhauer, A., Wallmann, K., Böhm, F., Fietzke, J., Liebetrau, V., Krabbenhöft, A., Farkaš, J., Tomašových, A., Raddatz, J., and Veizer, J.: The Phanerozoic $\delta^{88 / 86} \mathrm{Sr}$ record of seawater: New constraints on past changes in oceanic carbonate fluxes, Geochim. Cosmochim. Acta, 128, 249-265, doi:10.1016/j.gca.2013.10.006, 2014.

Wanamaker Jr., A. D., Heinemeier, J., Scourse, J. D., Richardson, C. A., Butler, P. G., Eiríksson, J., and Knudsen, K. L.: Very longlived mollusks confirm 17th century AD tephra-based radiocar- 
bon reservoir ages for north Icelandic shelf waters, Radiocarbon, 50, 399-412, 2008a.

Wanamaker Jr., A. D., Kreutz, K. J., Schöne, B. R., Pettigrew, N., Borns, H. W., Introne, D. S., Belknap, D., Maasch, K. A., and Feindel, S.: Coupled North Atlantic slope water forcing on Gulf of Maine temperatures over the past millennium, Clim. Dynam., 31, 183-194, 2008b.

Wanamaker Jr., A. D., Kreutz, K. J., Schöne, B. R., Maasch, K. A., Pershing, A. J., Borns, H. W., Introne, D. S., and Feindel, S.: A late Holocene paleo-productivity record in the western Gulf of Maine, USA, inferred from growth histories of the long-lived ocean quahog (Arctica islandica), Int. J. Earth Sci., 98, 19-29, doi:10.1007/s00531-008-0318-z, 2009.

Wanamaker Jr., A. D., Kreutz, K. J., Schöne, B. R., and Introne, D. S.: Gulf of Maine shells reveal changes in seawater temperature seasonality during the Medieval Climate Anomaly and the Little Ice Age, Palaeogeogr. Palaeocl., 302, 43-51, 2011.

Wanamaker Jr., A. D., Butler, P. G., Scourse, J. D., Heinemeier, J., Eiríksson, J., Knudsen, K. L., and Richardson, C. A.: Surface changes in the North Atlantic meridional overturning circulation during the last millennium, Nat. Commun., 3, 899, doi:10.1038/ncomms1901, 2012.

Weber, J. N.: Incorporation of strontium into reef coral skeletal carbonate, Geochim. Cosmochim. Acta, 37, 2173-2190, doi:10.1016/0016-7037(73)90015-X, 1973.

Weidman, C. R.: Development and Application of the Mollusc Arctica Islandica as a Paleoceanographic Tool for the North Atlantic Ocean, PhD thesis, Woods Hole Oceanographic Institution and the Massachusetts Institute of Technology, Cambridge, 1995.
Weidman, C. R. and Jones, G. A.: A Shell-Derived Time History of Bomb ${ }^{14} \mathrm{C}$ on Georges Bank and Its Labrador Sea Implications, J. Geophys. Res., 98, 14577-14588, 1993.

Weidman, C. R., Jones, G. A., and Lohman, L.: The long-lived mollusc Arctica islandica: A new paleoceanographic tool for the reconstruction of bottom temperatures for the continental shelves of the northern North Atlantic Ocean, J. Geophys. Res., 99, 18305-18314, 1994.

Widerlund, A. and Andersson, P. S.: Strontium isotopic composition of modern and Holocene mollusc shells as a palaeosalinity indicator for the Baltic Sea, Chem. Geol., 232, 54-66, 2006.

Witbaard, R. and Bergman, M. J. N.: The distribution and population structure of the bivalve Arctica islandica L. in the North Sea: what possible factors are involved?, J. Sea Res., 50, 11-25, 2003.

Yan, H., Shao, D., Wang, Y., and Sun, L.: Sr/Ca profile of longlived Tridacna gigas bivalves from South China Sea: A new highresolution SST proxy, Geochim. Cosmochim. Acta, 112, 52-65, doi:10.1016/j.gca.2013.03.007, 2013.

Yu, K.-F., Zhao, J.-X., Wei, G.-J., Cheng, X.-R., Chen, T.-G., Felis, T., Wang, P.-X., and Liu, T.-S.: $\delta^{18} \mathrm{O}, \mathrm{Sr} / \mathrm{Ca}$ and $\mathrm{Mg} / \mathrm{Ca}$ records of Porites lutea corals from Leizhou Peninsula, northern South China Sea, and their applicability as paleoclimatic indicators, Palaeogeogr. Palaeocl., 218, 57-73, 2005.

Zhang, Z.: Geochemical properties of shells of Arctica islandica (Bivalvia)-implications for environmental and climatic change, $\mathrm{PhD}$ thesis, Goethe-Universität in Frankfurt am Main, Frankfurt, 109 pp., 2009. 